\title{
New Records of Vascular Plants in the Yukon Territory V
}

\author{
William J. Cody ${ }^{1}$, Catherine E. Kennedy², Bruce Bennetr², and Jennifer Staniforth ${ }^{2}$. \\ ${ }^{1}$ National Program on Environmental Health, Agriculture and Agri-Food Canada, Research Branch, Central Experimental \\ Farm, Ottawa, Ontario K1A 0C6 Canada \\ ${ }^{2}$ Department of Environment, Government of Yukon, Box 2703, Whitehorse, Yukon Y1A 2C6 Canada
}

William J. Cody, Catherine E. Kennedy, Bruce Bennett, and Jennifer Staniforth. 2003. New records of vascular plants in the Yukon Territory V. Canadian Field-Naturalist 117(2): 278-301.

Based on field reconnaissance in 2000 and 2001 throughout Yukon but particularly in the areas of the Upper Bonnet Plume River, Wind River, Eagle Plains and Vuntut National Park, information is provided on geographically significant plant occurrences. Three native taxa, Draba kananaskis, Hieracium albiflorum and Prunella vulgaris ssp. lanceolata and five introduced taxa, Alopecurus geniculatus, Dactylis glomerata, Elymus junceus, Lotus corniculatus, and Verbena hastata are reported new to the known flora of the Yukon Territory. Signifigant range extensions for 190 native and 24 introduced taxa are included. Maianthemum dilatatum is excluded from the Yukon flora.

Key Words: Vascular plants, Yukon Territory, flora, new records, range extensions, phytogeography.

Since the writing of New Records of Vascular Plants in the Yukon Territory IV (Cody et al. 2002), a considerable number of plant specimens have been submitted to Cody for identification and confirmation. The major submissions include the following locations and collectors: (1) Vuntut National Park by Bruce Bennett in connection with habitat inventories done for the National Park Service; (2) Lands adjacent to the Wind River by Bruce Bennett partially funded by the Canadian Parks and Wilderness Society; (3) Lands adjacent to the Upper Bonnet Plume River near the border of the Northwest Territories by Jennifer Staniforth while documenting vegetation for Yukon Renewable Resources Department; (4) Southern part of the Yukon Territory by Rhonda Rosie for the Yukon Territory Government Parks Branch; (5) Peel River Plateau and Richardson Mountains by Rhonda Rosie with support from the Canadian Parks and Wilderness Society; (6) Richardson Mountains by Greg Brunner during a vegetation analysis required by the Canadian Parks and Wilderness Society; (7) Kluane National Park area by Phil Caswell for the National Park Service as part of ongoing botanical inventories; (8) Southern Yukon at several former mine sites by Stu Withers in connection with reclamation of vegetation and soil stabilization; (9) Trout Lake area in Ivavik National Park by Jennifer Line while undertaking taxonomic studies of Tofieldia.

This paper serves to further update the Flora of the Yukon Territory (Cody 1996) and Flora of the Yukon Territory, Second Edition (Cody 2000) along with other records recently published (Cody et al. 1998, 2000, 2001, 2002). The floristic information presented earlier and updated here is essential for biological research and ongoing work relating to agriculture, forestry, sustainable resource management and wildlife management. With additions of three native and five introduced species reported here the flora now includes 1171 species.
The new native species are all rare (as defined by Douglas et al. 1981). For convenience in this paper the Herbarium of the Yukon Department of Environment (formerly Yukon Department of Renewable Resources) has been given the acronym YUKH.

The taxa addressed in the body of this paper appear first in a synoptic list by Yukon status in alphabetical order. The taxa are then discussed in taxonomic order, as presented in the Flora of the Yukon Territory with citation of specimens and other pertinent information. Common names follow Cody (1996) and Douglas et al. (1984-2001).

\author{
Synoptic list by Yukon Status \\ Native taxa new to the Yukon Territory (3) \\ Draba kananaskis \\ Hieracium albiflorum \\ Prunella vulgaris ssp. lanceolata
}

Introduced taxa new to the Yukon Territory (5)

Alopecurus geniculatus

Dactylis glomerata

Elymus junceus

Lotus corniculatus

Verbena hastata

\section{Range Extensions of Native Taxa within the \\ Yukon Territory (190)}

Aconitum delphinifolium ssp. paradoxum

Adoxa moschatellina

Agrostis exarata

Agrostis mertensii ssp. mertensii

Agrostis scabra var. geminata

Alnus crispa ssp. crispa

Alnus incana ssp. tenuifolia

Andromeda polifolia

Anemone multifida

Antennaria rosea ssp. confinis

Aquilegia formosa

Arabis boivinii

Arabis codyi 
Arabis holboellii var. retrofracta

Arabis kamtschatica

Arnica angustifolia ssp. attenuata

Arnica chamissonis ssp. chamissonis

Arnica griscomii ssp. frigida

Artemisia dracunculus

Aster modestus

Astragalus bodinii

Astragalus tenellus

Betula neoalaskana

Betula occidentalis

Betula papyrifera

Bidens cernua

Calamagrostis canadensis ssp. canadensis

Calamagrostis canadensis ssp. langsdorfii

Calamagrostis purpurascens var. purpurascens

Calamagrostis stricta ssp. inexpansa

Cardamine umbellata

Carex arcta

Carex atherodes

Carex atrofusca

Carex bicolor

Carex bonanzensis

Carex brunnescens

Carex buxbaumii

Carex capillaris ssp. capillaris

Carex concinna

Carex deflexa

Carex eleusinoides

Carex flava

Carex franklinii

Carex garberi ssp. bifaria

Carex glacialis

Carex magellanica ssp. irrigua

Carex media

Carex microglochin

Carex obtusata

Carex pachystachya

Carex phaeocephala

Carex rostrata

Carex viridula

Carex williamsii

Castilleja pallida var. caudata

Cerastium arvense

Ceratophyllum demersum

Chrysanthemum integrifolium

Cicuta maculata var. angustifolia

Cinna latifolia

Circaea alpina ssp. alpina

Comandra umbellata ssp. pallida

Cystopteris fragilis

Cystopteris montana

Delphinium glaucum

Descurainia sophioides

Draba albertina

Draba borealis

Draba cana

Draba cinerea

Draba incerta

Draba macounii

Draba porsildii

Draba scotteri

Dryas crenulata

Dryas hookeriana
Dryopteris expansa

$\times$ Elyhordeum macounii

Elymus glaucus

Elymus macrourus

Elymus trachycaulus ssp. andinus

Elymus trachycaulus ssp. glaucus

Elymus trachycaulus ssp. novae-angliae

Elymus trachycaulus ssp. subsecundus

Elymus trachycaulus ssp. trachycaulus

Elymus trachycaulus ssp. violaceus

Epilobium hornemannii

Epilobium palustre

Equisetum variegatum ssp. variegatum

Eriophorum brachyantherum

Eriophorum callitrix

Eriophorum scheuchzeri

Eritrichium splendens

Erysimum cheiranthoides

Festuca lenensis

Festuca richardsonii

Festuca rubra

Fragaria virginiana ssp. glauca

Galium trifidum

Gymnocarpium dryopteris ssp. dryopteris

Hedysarum boreale ssp. mackenzii

Hierochloe alpina ssp. alpina

Iris setosa ssp. interior

Juncus balticus var. littoralis

Juncus triglumis ssp. albescens

Kalmia polifolia

Kobresia simpliciuscula

Lappula occidentalis

Leptarrhena pyrolifolia

Lesquerella arctica ssp. arctica

Lesquerella calderi

Lloydia serotina

Lycopodium alpinum

Lycopodium clavatum var. monostachyon

Lycopodium complanatum

Menyanthes trifoliata

Mimulus guttatus

Minuartia dawsonensis

Minuartia elegans

Minuartia obtusiloba

Minuartia yukonensis

Orobanche fasciculata

Osmorhiza depauperata

Oxytropis campestris ssp. roaldii

Oxytropis nigrescens ssp. nigrescens

Parnassia fimbriata

Pedicularis lanata

Phalaris arundinacea

Phlox hoodii

Pinus contorta ssp. latifolia

Poa leptocoma

Poa porsildii

Poa pratensis ssp. alpigena

Poa secunda ssp. secunda

Polemonium acutiflorum

Potamogeton filiformis var. borealis

Potamogeton vaginatus

Potentilla nivea

Primula egaliksensis

Puccinellia deschampsioides 
Puccinellia nuttalliana

Pyrola minor

Ranunculus aquatilis var. eradicatus

Ranunculus eschscholtzii

Ranunculus flammula

Ranunculus pedatifidus ssp. affinis

Rosa woodsii

Rubus pedatus

Rubus pubescens

Rumex acetosa ssp. alpestris

Salix alaxensis ssp. longistylis

Salix arbusculoides

Salix arctica

Salix arctophila

Salix commutata

Salix fuscescens

Salix hastata

Salix niphoclada

Salix polaris

Salix pseudomonticola

Salix richardsonii

Salix rotundifolia ssp. rotundifolia

Sanguisorba canadensis ssp. latifolia

Schizachne purpurascens

Scirpus caespitosus ssp. austriacus

Senecio indecorus

Senecio sheldonensis

Senecio streptanthifolius

Senecio tundricola

Sibbaldia procumbens

Silene acaulis ssp. acaulis

Silene involucrata ssp. involucrata

Silene taimyrensis

Solidago canadensis var. salebrosa

Solidago multiradiata

Sparganium minimum

Stellaria borealis

Stellaria longifolia

Stipa comata

Streptopus amplexifolius ssp. americanus

Subularia aquatica ssp. americana

Taraxacum lyratum

Thalictrum alpinum

Thalictrum sparsiflorum ssp. richardsonii

Utricularia minor

Veratrum viride ssp. eschscholtzii

Viola epipsila ssp. repens

Viola langsdorfii

Viola nephrophylla

Range Extensions of Introduced Taxa within the

Yukon Territory (24)

Agropyron pectiniforme

Agropyron sibiricum

Agrostis gigantea

Astragalus cicer

Bromus carinatus

Elymus elongatus ssp. ponticus

Elymus hispidus

Festuca trachyphylla

Lepidium sativum

Linaria vulgaris

Matricaria perforata

Onobrychis viciifolia

Phleum pratense

\author{
Plantago major \\ Poa compressa \\ Poa trivialis \\ Polygonum achoreum \\ Polygonum aviculare \\ Puccinellia distans \\ Senecio vulgaris \\ Sonchus asper \\ Spergularia rubra \\ Stellaria media \\ Trifolium pratense
}

\section{Comments on a Taxon excluded from the Yukon Territory (1) \\ Maianthemum dilatatum}

\section{LYCOPODIACEAE}

Lycopodium alpinum L., Alpine Club-moss - YUKON: undulating alpine midslope, Upper Bonnet Plume River Drainage, Site \#120, 64²4'45”N 132 07'1'W, J. Staniforth 00-078, 4-12 July 2000 (DAO); strongly mounded-graminoid/moss/lichen pediment with frost boils, Upper Bonnet Plume River Drainage Site \#131, 64³1'19”N 13251'39”'W, J. Staniforth 00-092, 4-12 July 2000 (DAO).

The specimens cited above are an extension of the known range in the Territory of about 175 kilometers east of a site mapped by Cody (1996) west of longitude $135^{\circ} \mathrm{W}$.

Lycopodium clavatum L. var. monostachyon Hook. \& Grev., Common Club-moss - Yukon: low damp area beside the water, WNW end of Trout Lake, $68^{\circ} 49^{\prime} 27^{\prime \prime} \mathrm{N}$ $138^{\circ} 45^{\prime} 8^{\prime}$ 'W, J. M. Line 2000-81, 28 July 2000 (DAO).

The specimen cited above is the northernmost yet found in the Territory. It is an extension of about 60 kilometers north of a site mapped by Cody (1996).

Lycopodium complanatum L., Flatbranch Club-moss - YUKON: Eagle Plains, 66¹6’06”N 138 24’52”W, G. Brunner 34b-00, 21 July 2000 (DAO); undulating lower slope, shrub thicket with pockets of lichen, Upper Bonnet Plume River Drainage Site \#111, $64^{\circ} 22^{\prime} 10^{\prime \prime N} 132^{\circ} 19^{\prime} 49^{\prime \prime} W, J$. Staniforth 00-056, 6 July 2000 (DAO).

The first specimen cited above is an extension of the known range about 100 kilometers west of a site mapped by Cody (1996) west of longitude $138^{\circ} \mathrm{W}$. The second specimen is an extension of the known range in the Territory of about 120 kilometers north of a site between longitudes $131^{\circ} \mathrm{W}$ and $132^{\circ} \mathrm{W}$.

\section{EQUISETACEAE}

Equisetum variegatum Schleich. ssp. variegatum, Variegated Horsetail - YUKON: undulating riparian willow zone, Upper Bonnet Plume River Drainage Site \#115, 64²5'03”N 132 22'56”'W, J. Staniforth 00-062, 7 July 2000 (DAO).

The specimen cited above is an extension of the known range in the Territory (Cody et al. 2001) of about 75 kilometers southeast of a site adjacent to the Snake River.

\section{AsPidiaceae}

Cystopteris fragilis (L.) Bernh., Fragile Fern - YUKON: undulating dry hummocky tundra alpine slope, Upper 
Bonnet Plume Drainage Site \#116, 64²4'28.7'N $132^{\circ} 07^{\prime} 54$ 'W, J. Staniforth 00-086, 7 July 2000, (DAO).

The specimen cited above is an extension of the known range in the Territory of about 140 kilometers to the northeast of a site east of Mayo mapped by Cody (1996).

Cystopteris montana (Lam.) Bernh., Mountain Bladder Fern - YUKON: undulating spruce/shrub/lowshrub/ forb/moss, Upper Bonnet Plume River Drainage Site \#105, 64 26' 6”'N 132 15'28”'W, J. Staniforth 00-016, 5 July 2000 (DAO); white spruce/willows, Richardson

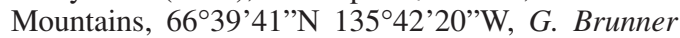
11-00, 14 July 2000 (DAO).

The first specimen cited above is an extension of the known range in the Territory of about 240 kilometers northeast of a site west of Mayo mapped by Cody (1996). The second specimen cited above which is the northernmost yet found in the Territory is about 125 kilometers north of a site adjacent to the Wind River reported by Cody et al. (2002).

Dryopteris expansa (Presl) Fraser-Jenkins \& Jermy, Northern Wood Fern - YUKON: alder/rose, Richardson Mts., 66²4'51'N 135'24'40”'W, G. Brunner 23-00, 17 July 2000 (YUKH, Photo DAO).

The specimen cited above is an extension of the known range in the Territory of about 500 kilometers southwest from sites adjacent to the North Canol Road mapped by Cody (1996).

Gymnocarpium dryopteris (L.) Newm. ssp. dryopteris, Oak Fern - YUKON: in moist alpine meadow, Crescent Lake, $60^{\circ} 11^{\prime} 00^{\prime \prime} \mathrm{N} 131^{\circ} 15^{\prime} 30^{\prime \prime} \mathrm{W}$, R. Rosie 2103, 22 July 2000 (DAO).

The specimen cited above is intermediate between sites mapped by Cody (1996) from the vicinity of Watson Lake and the South Canol Road.

\section{Pinaceae}

Pinus contorta Dougl. ex Loud. ssp. latifolia (Engelm.) Critchfield, Lodgepole Pine - YUKON: St. Elias Trail, Kluane National Park, $60^{\circ} 18^{\prime} \mathrm{N} 137^{\circ} 03^{\prime} \mathrm{W}$, P. Caswell 2000-Y-435, 18 Aug. 2000 (DAO).

The specimen cited above is an extension of the known range in the Territory of about 60 kilometers south of a site adjacent to the Alaska Hwy. just east of longitude $137^{\circ} \mathrm{W}$ reported by Cody et al. (2002).

\section{SPARGaniaCEAE}

Sparganium minimum (Hartm.) Fries, Small Bur-reed - YukON: submerged in shallow pond, Dog Creek Ponds, Vuntut National Park, 68²6’37' 'N 138 $45^{\circ}$ ' 12”W, B. Bennett 00-922, 7 Aug. 2000 (DAO).

The specimen cited above is an extension of the known range in the Territory of about 325 kilometers northwest of a site at Turner Lake reported by Cody et al. (2001).

\section{Potamogetonaceae}

Potamogeton filiformis Pers. var. borealis (Raf.) St. John, Fine-leaved Pondweed - YUKON: submerged in shallow pond, Dog Creek Ponds, Vuntut National Park, 68²6'37'N 138 45'12'”, B. Bennett 00-923, 7 Aug. 2000 (DAO); plant fragments washed ashore,
Trout Lake, 685'ㅅ $138^{\circ} 45^{\prime} \mathrm{N}$, J. M. Line 2000-139, 28 July 2000 (DAO).

The specimens cited above are an extension of the known range in the Territory of about 100 kilometers northeast of sites just north of latitude $68^{\circ} \mathrm{N}$ reported by Cody et al. (1998).

Potamogeton vaginatus Turcz., Giant Pondweed YuKON: submerged in shallow pond, Dog Creek Ponds, Vuntut National Park, 6826'37'N 138 $45^{\prime} 12^{\prime \prime} \mathrm{W}, B$. Bennett 00-924, 7 Aug. 2000 (DAO).

The specimen cited above is an extension of the known range in the Territory of about 125 kilometers northwest of a site about $67^{\circ} 40^{\prime} \mathrm{N}$ mapped by Cody (1996).

\section{Poaceae (Gramineae)}

Agropyron pectiniforme R. \& S., Crested Wheat Grass - YUKON: gravel disturbed area, Alaska Highway at Destruction Bay, $61^{\circ} 15^{\prime} 07.6^{\prime \prime} \mathrm{N} 138^{\circ} 48^{\prime} 19.8^{\prime \prime} \mathrm{W}$, Cody \& Cody 37070, 25 July 2000 (DAO).

The nearest site of this introduced grass species known to Cody (1996) was in the vicinity of Haines Junction, about 90 kilometers to the southeast.

Agropyron sibiricum (Willd.) P.B., Siberian Wheatgrass - YUKON: waste ground along roadside, Ross River, 61 $58^{\prime} 55.2^{\prime \prime} \mathrm{N} 132^{\circ} 26^{\prime} 57.0^{\prime} \mathrm{W}$, Cody \& Cody 36940, 19 July 2000 (DAO).

This introduced species was only known to Cody (1996) from two localities: Whitehorse and Carmacks.

Agrostis exarata Trin., Spike Redtop - YukON: in meadow along brook draining warm spring, McPherson Lake, 61'52'19'N 129³6'34'W, R. Rosie 2090, 6 Sept. 2000 (DAO).

Cody et al. (1998) extended the range of this rare species in the Territory (Douglas et al. 1981) to the vicinity of Frances Lake about 200 kilometers to the north of sites east of Watson Lake. The specimen cited above is a further extension to the north of about 30 kilometers.

Agrostis gigantea Roth, Creeping Bent Grass - YukON: reclaimed mining waste dump, Brewery Creek Mine, $64^{\circ} 03.3^{\prime} \mathrm{N} 138^{\circ} 03.3^{\prime} \mathrm{W}$, S. Withers SW00-102, 12 July 2000 (DAO); reclaimed area below leach pad, Brewery Creek Mine, $64^{\circ} 02.5^{\prime} \mathrm{N} 138^{\circ} 17.0^{\prime} \mathrm{W}, S$. Withers SW00-121, 13 July 2000 (DAO).

The specimens cited above of this introduced species are from only the third known locality in the Territory. It was previously known only from the vicinities of Dawson and Carmacks.

Agrostis mertensii Trin. ssp. mertensii, Red Bent Grass - YuKON: dry upland bench with Sibbaldia, north of camp "Dandelion Site", Vuntut National Park, $68^{\circ} 29.14^{\prime} \mathrm{N} 138^{\circ} 50.35^{\prime} \mathrm{W}$, B. Bennett 00-1150, 8 Aug. 2000 (DAO).

The specimen cited above is the northernmost yet found in the Territory (Cody 1996) and is an extension of the known range of about 125 kilometers to the northwest.

Agrostis scabra Willd. var. geminata (Trin.) Swallen - Yukon: reclaimed area near roadside, Sa Dena Hes Mine Site, $60^{\circ} 32.8^{\prime} \mathrm{N} 128^{\circ} 51.8^{\prime} \mathrm{W}$, S. Withers SWOO197, 31 Aug. 2000 (DAO). 
This variety was considered rare in the Territory by Douglas et al. (1981) where it was previously known from only five localities (Cody 1996; Cody et al. 1998).

Alopecurus geniculatus L., Water Meadow-foxtail (Figure 1) - YuKON: hidden in Stelleria longifolia clump, Horseshoe Slough Habitat Protection Area near Mayo, $63^{\circ} 26^{\prime} \mathrm{N} 135^{\circ} 06^{\prime} \mathrm{W}$, D. Mossop 8, July 2000 (DAO).

This species which is introduced in Canada from Eurasia is new to the Territory (Cody 1996). It is common in SW British Columbia north to the Queen Charlotte Islands and rare in SE British Columbia. It can be separated from $A$. alpinus as follows:

A. Spikes oblong to short-cylindric; spikelets more than $3 \mathrm{~mm}$ long; glumes densely covered over the entire surface with long wooly hairs;

lemma apices obtuse .............. alpinus

A. Spikes long-cylindric; spikelets $3.2 \mathrm{~mm}$ long or less; glumes with long hairs restricted to nerves and keel; lemma apices nearly truncate .......... geniculatus

Bromus carinatus Hook. \& Arn., California Brome YUKON: sandy silt riverbar with Salix alaxensis and Taraxacum officinale surrounding camp, La Biche River, $60^{\circ} 13.58^{\prime} \mathrm{N} 124^{\circ} 13.58^{\prime} \mathrm{W}$, B. Bennett 98-131, 17 June 1998 (DAO).

Cody (1996) knew this introduced species in the Territory from a single site in the vicinity of Carcross. Cody et al. (1998) reported a second site from the vicinity of Watson Lake. The specimen cited above is an extension of the known range in the Territory of about 250 kilometers to the east of Watson Lake.

Calamagrostis canadensis (Michx.) Beauv. ssp. canadensis, Blue-joint - YuKON: lake edge, Sam Lake, Vuntut National park, 68 $24^{\circ} 24^{\prime \prime} \mathrm{N} 138^{\circ} 37^{\prime} 58^{\prime \prime} \mathrm{W}, B$. Bennett 00-1144, 5 Aug. 2000 (DAO).

This is the northernmost collection yet found in the Territory. The nearest site known to Cody (1996) was about 85 kilometers to the southeast.

Calamagrostis canadensis (Michx.) Beauv. ssp. langsdorfii (Link) Hultén - YUKON: Beaver River near Toobally, $60^{\circ} 33.362^{\prime} \mathrm{N} 126^{\circ} 11.959^{\prime} \mathrm{W}$, B. Bennett 98-692, 14 Aug. 1998, (B. Bennett Herbarium, photo DAO); alpine meadow beside lake, Beavercrow Ridge, $60^{\circ} 13.38^{\prime} \mathrm{N} 124^{\circ} 34.834^{\prime} \mathrm{W}$, B. Bennett 98-688, 17 Aug. 1998 (DAO).

The specimens cited above extend the known range in the Territory (Cody 1996) about 150 kilometers east of a site west of longitude $127^{\circ} \mathrm{W}$.

Calamagrostis purpurascens R.Br. var. purpurascens, Purple Reedgrass - YUKON: subalpine, found with Trisetum spicatum and Festuca baffinensis, Kotaneelee Range, $60^{\circ} 14.31^{\prime} \mathrm{N} 124^{\circ} 07.19^{\prime} \mathrm{W}$, B. Bennett $98-708$, 19 June 1998 (DAO).

The specimen cited above is the easternmost yet found in the Territory (Cody 1996). It is an extension of about 80 kilometers east of a site adjacent to the Larsen Hotsprings reported by Cody et al. (2000).

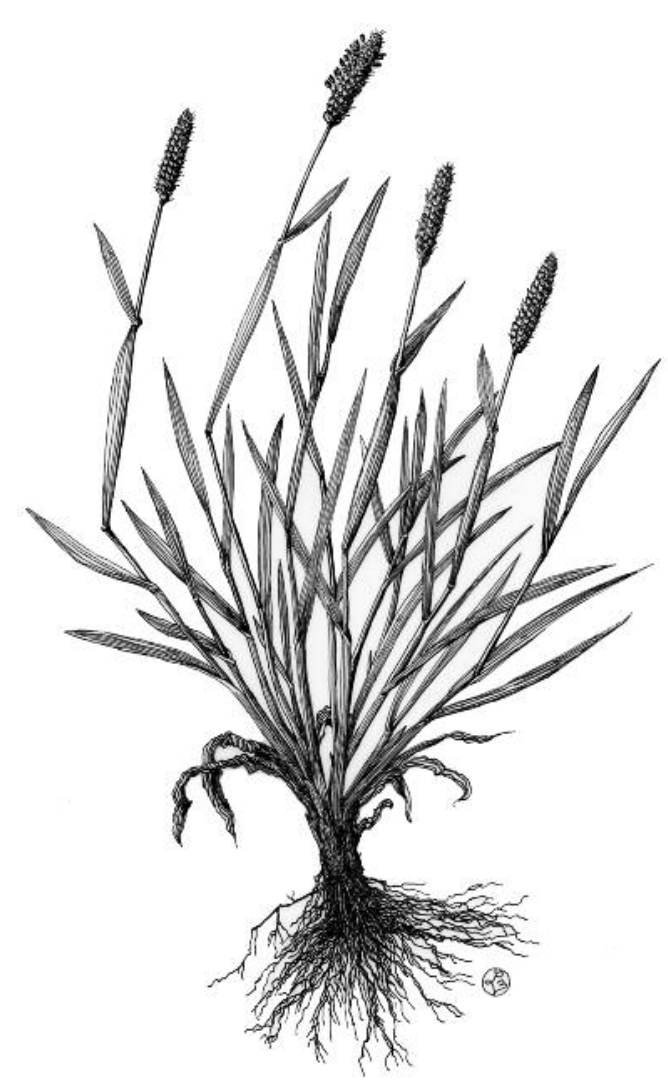

FIGURE 1. Alopecurus geniculatus L., Water Meadow-foxtail (drawn by Lee Mennell).

Calamagrostis stricta (Timm) Koeler ssp. inexpansa (Gray) C. W. Greene, Northern Reedgrass - YUKON: detachment slide, Richardson Mts., $66^{\circ} 52^{\prime} \mathrm{N} 135^{\circ} 50^{\prime} \mathrm{W}$, G. Brunner 22-00, 17 July 2000, (DAO); loose sand near top of beach, Taco Bar, Peel River, $66^{\circ} 00^{\prime} 15^{\prime \prime} \mathrm{N}$ $134^{\circ} 13^{\prime} \mathrm{W}$, B. Bennett 00-390, 13 July 2000 (DAO); huge riverbar system, Peel River Camp \#8, 65 ${ }^{\circ} 56.03^{\prime} \mathrm{N}$ $134^{\circ} 58.84^{\prime} \mathrm{W}$, B. Bennett 00-774, 9 July 2000 (DAO).

The specimens cited above extend the known distribution in the Territory about 150 kilometers to the southeast from a site north of the Dempster Hwy. known to Cody (1996).

Cinna latifolia (Trev.) Griseb., Nodding Wood-reed YUKON: in meadow along brook draining warm spring, McPherson Lake, 61 ${ }^{\circ} 52$ '19'” 129³6'34'W, R. Rosie 2091, 6 Sept. 2000 (DAO).

Cody et al. (1998) extended the known range of this rare species in the Territory (Douglas et al. 1981) to the vicinity of Frances Lake about 200 kilometers north of a site east of Watson Lake. The specimen cited above is a further extension to the north of about 30 kilometers.

Dactylis glomerata L., Orchard Grass (Figure 2) YUKON: disturbed area near tailings dam, Sa Dena Hes Mine Site, $60^{\circ} 32.8^{\prime} \mathrm{N} 128^{\circ} 51.8^{\prime} \mathrm{W}$, S. Withers SW00-176, 31 Aug. 2000 (B. Bennett Herbarium, 

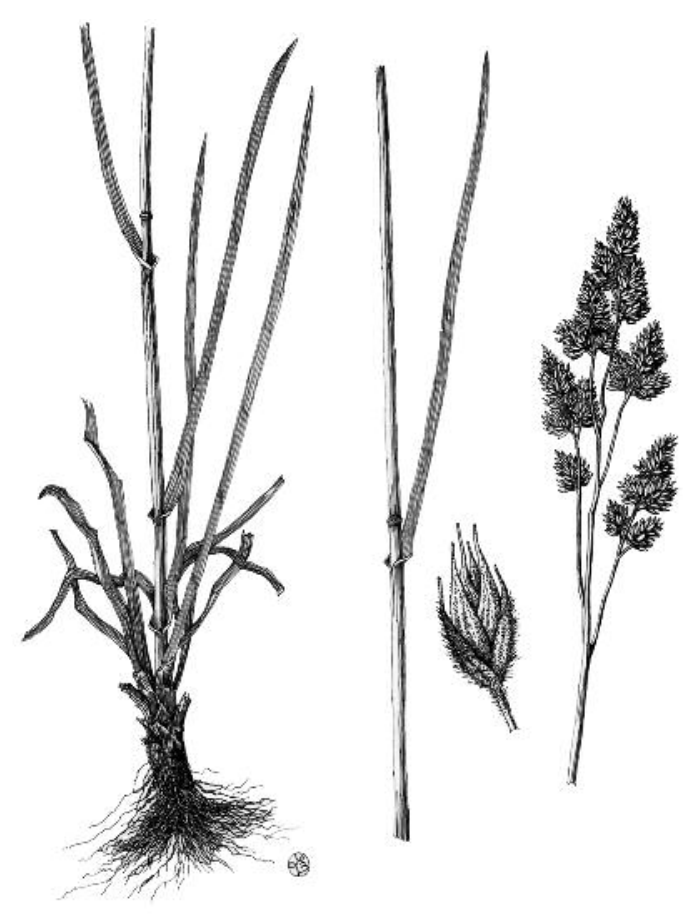

Figure 2. Dactylis glomerata L., Orchard Grass (drawn by Lee Mennell).

photo DAO); reclaimed area near roadside, Sa Dena Hes Mine Site, $60^{\circ} 32.8^{\prime} \mathrm{N}^{\prime} 128^{\circ} 51.8^{\prime} \mathrm{W}$, S. Withers SW00-198, 31 Aug. 2000 (DAO).

The specimens cited above are the first records of this introduced species in the Territory. Cody (1996) suggested that it should be looked for in areas north of the British Columbia border.

$\times$ Elyhordeum macounii (Vasey) Barkworth \& D. R. Dewey ( $\times$ Agrohordeum macounii (Vasey) Lepage, Elymus macounii Vasey) - YukON: only seen in one small patch near salt lake, Takhini Salt Flats, $60^{\circ}$ 51.23'N $135^{\circ} 42.55^{\prime} \mathrm{W}$, B. Bennett 99-213, 26 July 1999 (DAO) (determined by S. Darbyshire).

Porsild (1951) knew this hybrid from Hootalinqua on the Yukon River, Mayo and Mile 937 (ca Km 1558) on the Alaska Hwy. and in addition a specimen collected by Malte from Dawson was revised to Agrohordeum macounii. xAgrohordeum macounii was reported as occurring in the Yukon Territory by Cody (1996).

Elymus elongatus (Host) Runemark ssp. ponticus (Podp.) Melderis, Tall Wheatgrass - YuKON: disturbed area near tailings dam, Sa Dena Hes Mining Site, $60^{\circ} 32.8^{\prime} \mathrm{N} 128^{\circ} 51.8^{\prime} \mathrm{W}, \mathrm{S}$. Withers SW00-183, 31 Aug. 2000 (DAO); reclaimed area near roadside, same locality, S. Withers SW00-200, 31 Aug. 2000 (DAO).
This introduced species was first reported from a site south of Carcross at the British Columbia border by Cody et al. (2002). It was presumably the result of planting seeds to reclaim eroding soil in the area cited above.

Elymus glaucus Buckl., Western Rye Grass reclaimed mining waste dump, Brewery Creek Mine, $64^{\circ} 03.3^{\prime} \mathrm{N} 138^{\circ} 03.2^{\prime} \mathrm{W}$, S. Withers SW00-109, 12 July 2000 (DAO).

This species was previously known in the Territory in the southwest (Cody 1996) and extreme southeast (Cody et al. 2000). It was undoubtedly introduced at the site listed above.

Elymus hispidus (Opiz) Meld. (Agropyron intermedium (Host) Beauv., Elytrigia intermedia (Host) Nevski), Intermediate Wheatgrass - YUKON: disturbed roadside, Robert Campbell Hwy., Km 467, 62 10.20’N 134²18'W, B. Bennett 99-542, 19 Aug. 1999 (DAO).

Cody et al. (1998) reported the first occurrence of this introduced Eurasian species in the Territory from a roadside adjacent to the La Biche River about 600 kilometers southeast of the introduction cited above. In addition a second specimen has since been collected in the southeast in a disturbed area beside the La Biche Airstrip, $60^{\circ} 07^{\prime} 42^{\prime \prime} \mathrm{N} 124^{\circ} 02^{\prime} 21^{\prime \prime} \mathrm{W}$, B. Bennett 98-581, 21 June 1998 (DAO). These Bennett specimens were accidentally reported as Elymus repens by Cody et al. (2000).

Elymus junceus Fischer (Psathyrostachys juncea (Fischer) Nevski), Russian Wild Rye - YUKON: Kluane National Park, Haines Hwy. ca Km 195 at Dezadeash Lake Pull Out, 60²2'46.0'N 137'03'8.9'W, P. Caswell s.n., 19 July 2000 (Kluane National Park Herbarium, photo DAO) (determined by S. Darbyshire).

This species, which is introduced from Asia, is new to the Yukon Territory. Elsewhere in North America it is known from the Prairie Provinces and south to Arizona.

Densely tufted perennial; culms 30-120 cm high, erect or decumbent at base; old sheath bases more or less persistent; leaf blades flat to involute, $1-5 \mathrm{~mm}$ wide, glabrous to scaberulous; spike 3-16 cm long, 5-17 mm wide, erect, the rachis at maturity disarticulating; spikelets 2(3) per node, 7-10(12) mm long (excluding awns), strongly overlapping; glumes subulate, (4) 5-9 mm long, obscurely 1-nerved, acute to awn-tipped, distinctly shorter than the lowermost lemma; lemma lanceelliptical, 6-10 mm long, scabrous to densely short-hairy, tapered to a sharply acute tip or with an awn to about $3 \mathrm{~mm}$ long; anthers $2.5-5 \mathrm{~mm}$ long.

Elymus macrourus (Turcz.) Tzvelev, Thick-spike Wild Rye - Yukon: on gravel bar of Peel River, Peel River Plateau, 66 50'30'N 134 57'00'W, R. Rosie 2147, 17 July 2000 (DAO).

The specimen cited above is an extension of the known range in the Territory (Cody 1996) of about 60 kilometers east of a site adjacent to the Dempster Hwy.

Elymus trachycaulus (Link) Gould ex Shinners ssp. trachycaulus, Slender Wheatgrass - YUKON: common on riverbar, Wind River Camp \#4, 65 $22.89^{\prime} \mathrm{N}$ $135^{\circ} 26.1^{\prime} \mathrm{W}$, B. Bennett 00-370, 5 July 2000 (DAO).

The specimen cited above is an extension of the known range in the Territory (Cody 1996) of about 200 kilometers north of a site in the vicinity of Mayo. 
Elymus trachycaulus (Link) Gould ssp. andinus (Scribn. \& Smith) A. \& D. Löve - YuKON: riverbar in sand, Dog Creek Camp, Vuntut National Park, $68^{\circ} 27.53$ 'N $138^{\circ} 44.47^{\prime} \mathrm{W}$, B. Bennett 00-1189, 3 Aug. 2000 (DAO); large arctic ground squirrel mound on tundra, Dog Creek Ponds, Vuntut National Park, $68^{\circ} 26.37^{\prime} \mathrm{N} 138^{\circ} 45.12^{\prime} \mathrm{W}$, B. Bennett 00-1190, 8 Aug. 2000 (DAO).

The specimens cited above are the northernmost yet found in the Territory (Cody 1996). The nearest known site is about 100 kilometers to the southwest.

Elymus trachycaulus (Link) Gould ex Shinners ssp. glaucus (Pease \& Moore) Cody - YUKON: start of trail in John Connally RV Park, 62 ${ }^{\circ} 13^{\prime} 51.29^{\prime \prime} \mathrm{N} 133^{\circ} 21^{\prime}$ 02.65'W, B. Bennett 99-539, 19 Aug. 1999 (DAO); loose sand near top of beach, Taco Bar, Peel River, $66^{\circ} 00.15^{\prime} \mathrm{N} 134^{\circ} 13^{\prime} \mathrm{W}, B$. Bennett 00-393, 13 July 2000 (DAO).

The first specimen cited above is an extension of the known range in the Territory (Cody 1996) of about 100 kilometers north of a site adjacent to the South Canol Road. The nearest site to the second specimen is about 250 kilometers to the northwest adjacent to the Porcupine River.

Elymus trachycaulus (Link) Gould ex Shinners ssp. novae-angliae (Scribn.) Tzvelev - YUKON: on gravel bar of Caribou River, 66 $6^{\circ} 15^{\prime} 41^{\prime \prime} \mathrm{N} 135^{\circ} 31^{\prime} 28^{\prime \prime} \mathrm{W}, R$. Rosie 2149, 15 July 2000 (DAO); on gravel bar of Peel River, Peel River Plateau, 66 50'30'N 134'57'W, $R$. Rosie 2148, 17 July 2000 (DAO) (determined by $\mathrm{S}$. Darbyshire).

The specimens cited above are the northernmost yet found in the Territory (Cody 1996). They extend the known range about 290 kilometers northwest of a site adjacent to the Upper Bonnet Plume River.

Elymus trachycaulus (Link) Gould ex Shinners ssp. subsecundus (Link) Gould - YUKON: in crack of bedrock on exposed cliff, Wolf River/Nisutlin River confluence, $60^{\circ} 16.54^{\prime} \mathrm{N} 132^{\circ} 33.1^{\prime} \mathrm{W}$, B. Bennett 99-502, 16 Aug. 1999 (DAO); under Pinus contorta in sand, Nisutlin River, end of old beach ridge, B. Bennett 98586, 29 July 1998 (DAO).

The specimens cited above extend the known range in the Territory (Cody 1996) about 50 kilometers east of a site adjacent to Jake's Corner in the south.

Elymus trachycaulus (Link) Gould ex Shinners ssp. violaceus (Hornem.) A. \& D. Löve - YuKON: river-

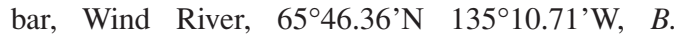
Bennett 00-798, 8 July 2000 (DAO) (determined by S. Darbyshire).

The specimen cited above is an extension of the known range in the Territory (Cody 1996) of about 75 kilometers to the southeast of a site north of latitude $66^{\circ} \mathrm{N}$.

Festuca lenensis Drob., Tundra Fescue - YUKON: on dry stony mountain top, Richardson Mts., 66 38'N $135^{\circ} 51^{\prime} \mathrm{W}, R$. Rosie 2150, 16 July 2000 (DAO).

The specimen cited above is an extension of the known range in the Richardson Mts. (Cody 1996) of about 50 kilometers south from the Dempster Hwy. at the Northwest Territory boundary.
Festuca richardsonii Hook., Richardson's Fescue YUKON: reclaimed area near roadside, Sa Dena Hes Mine Site, 60³2.8'N $128^{\circ} 51.8^{\prime} \mathrm{W}$, S. Withers SW00194, 31 Aug. 2000 (DAO); common on riverbar, Little Wind River/Wind River confluence, 65'22.89'N $135^{\circ} 26.1^{\prime} \mathrm{W}$, B. Bennett 00-373, 5 July 2000 (DAO); riverbar near more established willows, Peel River

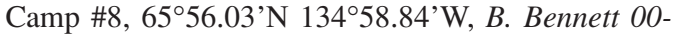
770, 9 July 2000 (DAO).

The first specimen cited above is an extension of the known range in the Territory (Cody 1996) of about 250 kilometers to the southeast from sites adjacent to the northern part of South Canol Road. The other two specimens are the first records of this species between latitudes $64^{\circ} \mathrm{N}$ and $66^{\circ} \mathrm{N}$ east of the Dempster Hwy.

Festuca rubra L. s.1., Red Fescue - YUKON: riverbar, Wind River Camp \#6, 6540.46’N 135¹1.76’W, B. Bennett 00-860, 7 July 2000 (DAO); sandy gravel clearing, Top of the World Hwy., Km 23, 6408' 05.0”N 139॰44'27.0"W, Cody \& Cody 37035, 22 July 2000 (DAO) (determined by S. Darbyshire).

Cody (1996) knew this species in the Territory only as far north as about latitude $64^{\circ} 30^{\prime} \mathrm{N}$ adjacent to the Dempster Hwy. The first specimen cited above is the northernmost yet found in the Territory and is an extension of the known range of about 140 kilometers east of sites adjacent to the Dempster Hwy. The second specimen is the first record from the Top of the World Hwy.

Festuca trachyphylla L., Hard Fescue - YUKON: reclaimed mining waste dump, Brewery Creek Mine, $64^{\circ} 03.3^{\prime} \mathrm{N} 138^{\circ} 03.2^{\prime} \mathrm{W}, \mathrm{S}$. Withers SW00-112, SWOO$116 A, 12$ July 2000 (DAO); open roadside and reclaimed area near roadside, Sa Dena Hes Mine Site, 60³2.8'N 128 51.8'W, S. Withers SW00-195, SW00209, 31 Aug. 2000 (DAO); seeded gravel slope, Campbell Hwy. Km 380, 62 03 '34.2'N 132 $2^{\circ}$ ' 82.2’'W, Cody \& Cody 37584, 30 July 2001 (DAO).

Cody (1996) knew this introduced species only from the vicinity of Dawson. Cody et al. (2001) recorded a second site from adjacent to the Alaska Hwy. between Kluane Lake and the Alaska border. The first specimen cited above is from a site about 60 kilometers east of Dawson and the second site is from the southeast about 50 kilometers north of Watson Lake. The last site is from an area just northwest of Ross River.

Hierochloe alpina (Sw.) R. \& S. ssp. alpina, Alpine Holy Grass - YUKON: talus slope near river, Decep-

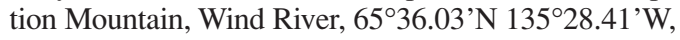
B. Bennett 00-418, 7 July 2000 (DAO).

The specimen cited above is the first known record from the Wind River area in the Territory (Cody 1996). It is however known from the Bonnet Plume River to the southwest and from north of the Peel River to the north.

Phalaris arundinacea L., Reed Canary Grass YUKON: Quill Creek, Kluane National Park, 6040’N $137^{\circ} 22^{\prime} \mathrm{W}$, P. Caswell 2000-Y-436, 17 July 2000 (DAO).

This species was considered rare in the Territory by Douglas et al. (1981). The specimen cited above is an extension of the known range in the Territory (Cody 1996) of about 150 kilometers west of a site in the vicinity of Whitehorse. 
Phleum pratense L., Timothy - YUKON: open roadside, Sa Dena Hes Mine Site, 60 $32.8^{\prime} \mathrm{N} 128^{\circ} 51.8^{\prime} \mathrm{W}$, S. Withers SW00-232, 31 Aug. 2000 (DAO).

Timothy is not a common introduction in southeastern Yukon. The specimen cited above is from a site about 90 kilometers northwest of a site east of Watson Lake.

Poa compressa L., Canada Bluegrass - YUKON: open roadside, Sa Dena Hes Mine Site, $60^{\circ} 32.8^{\prime} \mathrm{N} 128^{\circ}$ 51.8'W, S. Withers SW00-223, 1 Sept. 2000 (DAO).

This is not a common introduction in the Yukon. Cody (1996) knew it only from the vicinity of Whitehorse and the South Canol Road. The specimen cited above is from about 225 kilometers east of the Canol Road.

Poa leptocoma Trin., Bog Bluegrass - YUKON: exposed alpine ridge, north slope of Golden Horn Mountain, $60^{\circ} 34.2^{\prime} \mathrm{N} 135^{\circ} 03.2^{\prime} \mathrm{W}, \mathrm{S}$. Withers SW00-170, 24 Aug. 2000 (DAO).

This is a widely scattered species throughout the Territory (Cody 1996). The specimen cited above is from about 200 kilometers east of a site near the south end of Kluane Lake.

Poa porsildii Gjaerevoll - Yukon: undulating upper slope, moist hummocky tundra, Upper Bonnet Plume River Drainage Site \#108, 64²8'05'N 132 04 '15”W, J. Staniforth 00-039, 5 July 2000 (DAO).

The specimen cited above is an extension of the known range in the Territory (Cody 1996) of about 135 kilometers to the northeast and about 175 kilometers from the east end of North Canol road to the southeast.

Poa pratensis L. ssp. alpigena (Blytt) Hiit. - YUKON: open meadow near outfitter's camp, Wind River, McClusky Lake, $64^{\circ} 34.19^{\prime} \mathrm{N} 134^{\circ} 25.77^{\prime} \mathrm{W}$, B. Bennett 00-243, 2 July 2000 (DAO).

The specimen cited above is an extension of the known range in the Territory (Cody 1996) of about 125 kilometers northeast of a site in the vicinity of Mayo.

Poa secunda Presl ssp. secunda, Sandberg Bluegrass - YUKON: riverbank, 4' above river, silty sand with cobbles, La Biche River, $60^{\circ} 04.22^{\prime} \mathrm{N} 124^{\circ} 03.09^{\prime} \mathrm{W}$, B. Bennett 95-165, 12 June 1995 (DAO).

The specimen cited above is an extension of the known range in the Territory (Cody 1996) of about 200 kilometers east of a site adjacent to the Coal River Springs (Cody et al. 2000).

Poa trivialis L., Rough Bluegrass - YUKON: open roadside, southwest facing 15 degree slope, Sa Dena Hes Mine Site, $60^{\circ} 32.8^{\prime} \mathrm{N} 128^{\circ} 51.8^{\prime} \mathrm{W}, \mathrm{S}$. Withers SWOO212, 1 Sept. 2000 (DAO).

The specimen cited above is an extension of the known range of this introduced species in the Territory (Cody 1996) of about 240 kilometers east of a site adjacent to the Canol Road.

Puccinellia deschampsioides Th. Sor., Polar Alkali Grass - YUKON: on disturbed gravel near float plane landing, Johnson Lake, Faro, $62^{\circ} 12.23^{\prime} \mathrm{N} 133^{\circ} 23$. 112'W, B. Bennett 99-551, 19 Aug. 1999 (DAO).

Douglas et al. (1981) considered this species rare in the Territory. The specimen cited above is an extension of about
175 kilometers southeast of a site adjacent to Pelly Crossing mapped by Cody (1996).

Puccinellia distans (Jacq.) Parl., Spreading Alkali Grass - YUKON: sporadic in patches near fence, Takhini Salt Flats, $60^{\circ} 51.23^{\prime} \mathrm{N} 135^{\circ} 42.55^{\prime} \mathrm{W}, B$. Bennett 99-224, 26 July 1999 (DAO) (determined by S. Darbyshire); roadside gravel, Tagish Campground, $60^{\circ} 18^{\prime} 58.2^{\prime \prime} \mathrm{N} 134^{\circ} 15^{\prime} 17.9^{\prime \prime} \mathrm{W}$, Cody \& Cody 36924, 18 July 2000 (DAO); gravel area by closed restaurant, Robert Campbell Hwy., Km 467.5, 62¹1'58.4'N $134^{\circ} 22^{\prime} 14.4^{\prime \prime} \mathrm{W}, \mathrm{E}$ of Drury Creek, Cody \& Cody 36984, 20 July 2000 (DAO); roadside gravel pit, Campbell Hwy., Km 386, 61 '59'25.8'N 132²6'14”'W, Cody \& Cody 36985, 20 July 2000 (DAO) (determined by L. Consaul).

Cody (1996) considered this introduced species rare in the Territory. The first specimen cited above is an extension of about 100 kilometers east of a site northwest of Haines Junction. The second and third specimens extend the known range southeast of Whitehorse and along the Campbell Hwy. to near Ross River.

Puccinellia nuttalliana (Schult.) Hitchc., Nuttall's Alkali Grass - YUKON: gravel cleared area, Faro, $62^{\circ} 13^{\prime} 59.2^{\prime \prime} \mathrm{N} 133^{\circ} 20^{\prime} 57.8^{\prime}$ 'W, Cody \& Cody 36968, 19 July 2000 (DAO) (determined by L. Consaul).

The specimen cited above is an extension of the known range in the Territory of about 110 kilometers southeast of a site northeast of Carmacks mapped by Cody (1996).

Schizachne purpurascens (Torr.) Swallen, False Melic - YUKON: on steep dry west-facing slope in valley, Crescent Lake, $60^{\circ} 11^{\prime} 00^{\prime \prime} \mathrm{N} 131^{\circ} 09^{\prime} 30^{\prime \prime} \mathrm{W}$, R. Rosie 2117, 22 July 2000 (DAO).

Although this species is widespread in distribution, it is rare in the Yukon Territory where it is known only in the southeast (Cody 1996; Cody et al. 1998). The specimen cited above is intermediate between sites west of $127^{\circ} \mathrm{W}$ and $133^{\circ} \mathrm{W}$.

Stipa comata Trin. \& Rupr., Needle-and-Thread YUKON: south-facing slope in sandy well drained soil, Canyon Creek draining Aishihik Lake, $60^{\circ} 51.31^{\prime} \mathrm{N}$ $137^{\circ} 04.15^{\prime} \mathrm{W}$, B. Bennett 01-002, 21 April 2001 (DAO).

Cody (1996) knew this species in the Territory from only four locations between Whitehorse and just north of the Pelly River. The specimen cited above is from a site about 75 kilometers southwest of the nearest site known to Cody.

\section{Cyperaceae}

Carex arcta Boott, Northern Clustered Sedge YUKON: in moist meadows in valley near Rudy Lakes, $60^{\circ} 13^{\prime} 00^{\prime \prime N} 131^{\circ} 12^{\prime} 30^{\prime \prime} \mathrm{W}$, R. Rosie 2111, 23 July 2000 (DAO).

This species was considered rare in the Territory by Douglas et al. (1981). The specimen cited above is from a site about 60 kilometers east of a site east of Teslin.

Carex atherodes Spreng., Awned Sedge - Yukon: red rock seep near confluence with Peel River, Wind River, $65^{\circ} 50^{\prime} \mathrm{N} 135^{\circ} 18^{\prime} \mathrm{W}$, B. Bennett 00-451, 8 July 2000 (DAO). 
The specimen cited above is the northernmost yet found in the Territory (Cody 1996). It is from a site about 280 kilometers northeast of Dawson.

Carex atrofusca Schk., Dark-brown Sedge - YUKON: undulating lower slope, Dryas outwash floodplain, Upper Bonnet Plume River Drainage, 64³2'10'N 132 19'40'W, J. Staniforth 00-052, 6 July 2000 (DAO); muddy slough on riverbar, Wind River, $65^{\circ} 12.49^{\prime} \mathrm{N} 135^{\circ} 13.17^{\prime} \mathrm{W}$, B. Bennett 00-455, 5 July 2000 (DAO).

Cody et al. (2000) reported a collection from the headwaters of the Bonnet Plume River about 45 kilometers east of the specimen cited above. These are only the second and third known sites between latitudes $64^{\circ} \mathrm{N}$ and $66^{\circ} \mathrm{N}$ east of the Dempster Hwy.

Carex bicolor All., Two-coloured Sedge - YUKON: wet creek bank with Equisetum, upper Sheep Creek, $61^{\circ} 34.5^{\prime} \mathrm{N} 133^{\circ} 02.4^{\prime} \mathrm{W}, S$. Withers SW00-022A, 2 July 2000 (B. Bennett Herbarium, photo DAO).

This is a rare widely scattered species in the Territory (Cody 1996). The nearest site to that listed above is in the vicinity of Frances Lake, about 230 kilometers to the east.

Carex bonanzensis Britt., Yukon Sedge - YuKON: wetland, Richardson Mts., 66 $11^{\circ}$ '04'N 136 $25^{\circ} \mathrm{W}$, G. Brunner 31-00, 18 July 2000 (DAO).

The specimen cited above is intermediate between sites mapped by Cody (1996) from about 275 kilometers southwest adjacent to the Dempster Hwy. and from about 200 kilometers northwest adjacent to the Porcupine River.

Carex brunnescens Poir., Brownish Sedge - YuKON: Auriol Trail, Kluane National Park, 6042'N $137^{\circ} 27^{\prime} \mathrm{W}$, P. Caswell PPC-2000-Y-300, 10 Aug. 2000 (DAO).

The specimen cited above is an extension of the known range in the Territory (Cody 1996) of about 200 kilometers to the west from a site adjacent to Jake's Corner.

Carex buxbaumii Wahlenb., Buxbaum's Sedge YUKON: wet sedge meadow, north shore of Caribou Lake, 60³1.9'N 134¹6.9'W, S. Withers SW00-141, 29 July 2000 (DAO); "Cranberry Lake", Kluane National Park, 60¹6'40'”N 137³7'30'”W, R. D. Wickstrom s.n., 14 Aug. 1974 (DAO).

Cody (1996) knew this species in the Territory only from six localities, all south of latitude $62^{\circ} \mathrm{N}$. Since that time Cody et al. $(1998,2000)$ have added sites at Frances Lake and the Nisutlin River Delta. The first specimen cited above is intermediate between the Nisutlin River Delta and Whitehorse and the second specimen is an extension of the known range of about 130 kilometers south from the vicinity of Kluane Lake.

Carex capillaris L. ssp. capillaris, Hairlike Sedge YUKON: open meadow near outfitter's camp, McClusky Lake, Wind River, 64³4.19'N 134²5.77'W, B. Bennett 00-286, 2 July 2000 (DAO); amongst Salix and Parnassia at edge of river in camp, same locality, B. Bennett 00-338, 2 July 2000 (DAO); riverbar at base of cliff, Wind River, $65^{\circ} 12.49^{\prime} \mathrm{N} 135^{\circ} 13.17^{\prime} \mathrm{W}$, B. Bennett 00-369, 5 July 2000 (DAO); moist draw near creekside in gravelly soil, Wind River Camp \#6, $65^{\circ} 40.46^{\prime} \mathrm{N} 135^{\circ} 11.76^{\prime} \mathrm{W}$, B. Bennett 00-845, 7 July 2000 (DAO).

The specimens cited above are new to the area between latitudes $64^{\circ}$ and $66^{\circ} \mathrm{N}$ east of the Hart River.

Carex concinna R.Br., Low Northern Sedge - YUKON: moist meadow under Salix alaxensis, Dog Creek Camp, Vuntut National Park, 68²7'53'N 13844'47''W, B. Bennett 00-1033, 3 Aug. 2000 (DAO).

The specimen cited above is only the second known to Cody (1996) from north of $68^{\circ} \mathrm{N}$.

Carex deflexa Hornem., Bent Sedge - YuKON: Eagle Plains, 66 33'N 136² ${ }^{\circ}$ 'W, L. Schroeder 15, 24 July 1994 (DAO).

The specimen cited above is the northernmost yet found in the Territory (Cody 1996). It is an extension of about 60 kilometers north of a site just north of latitude $66^{\circ} \mathrm{N}$.

Carex eleusinoides Turcz., Goosegrass Sedge - YUKON: wet and waterlogged tussock tundra, Dog Creek Camp, Vuntut National Park, 68²7.53'N 138 44.47'W, B. Bennett 00-1170, 4 Aug. 2000 (DAO).

The specimen cited above is the northernmost yet found in the Territory (Cody 1996). It is an extension of the known range of about 75 kilometers northwest of a site just south of latitude $68^{\circ} \mathrm{N}$.

Carex flava L., Yellow Sedge - YUKON: along gravelly/ sandy beach near warm spring, McPherson Lake, 6152'19'N 129³6'34'W, R. Rosie 2088, 6 Sept. 2000 (DAO).

This species, which is rare in the Territory (Cody 1996) was previously known from a single locality about 80 kilometers east of Watson Lake. The specimen cited above is an extension of the known range of about 230 kilometers to the northwest.

Carex franklinii Boott, Franklin's Sedge - YUKON: riverbar, Wind River Outfitter's Camp, 64³4.43'N 134²8.88'W, B. Bennett 00-476, 2 July 2000 (DAO); Wind River Camp \#1, 6440.39'N 134³5.96’W, B. Bennett 00-733, 2 July 2000 (DAO); open dolomite delta in silty creek-bed, Wind River, 64\%48.46'N 13441.34'W, B. Bennett 00-323 (B. Bennett Herbarium, photo DAO); steep solifluction slope, Dog Creek Camp, Vuntut National Park, 68 27.53'N 138 $44.47^{\circ} \mathrm{W}$, B. Bennett 00-1065, 7 Aug. 2000 (DAO).

The Wind River specimens cited above are an extension of the known range in the Territory (Cody 1996) of about 125 kilometers southeast of a site adjacent to the Hart River. The Dog Creek Camp specimen is an extension of the known range in the far north of about 75 kilometers from sites adjacent to the Firth River.

Carex garberi Fern. ssp. bifaria (Fern.) Hultén, Garber's Sedge - YuKON: silty mud on edge of lake, Wind River Camp \#2, 64⒌51.83'N 134³8.85'W, B. Bennett 00-828, 4 July 2000 (DAO); silty seep on edge of river, Peel River, 65 $58.06^{\prime} \mathrm{N} 134^{\circ} 49.69^{\prime} \mathrm{W}, B$. Bennett 00-431, 10 July 2000 (DAO); silty hard packed river bank with Parnassia palustris under Salix alaxensis, Dog Creek Camp, Vuntut National Park, $68^{\circ} 27$. 
53’N 138 44.47’W, B. Bennett 00-1037, 4 Aug. 2000 (DAO).

Cody (1996) knew this sedge species only as far north as about $64^{\circ} \mathrm{N}$ in the vicinity of Dawson. The Wind and Peel river specimens cited above extend the known range in the Territory about 250 kilometers north of a site in the vicinity of Mayo. The Dog Creek specimen is an extension of the known range in the Territory of about 525 kilometers north of Dawson.

Carex glacialis Mack., Glacier Sedge - YukON: on steep vegetated slope above river, Wind River Camp

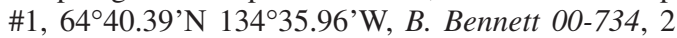
July 2000 (DAO); high alpine in loose talus, Wind River, $64^{\circ} 48.46^{\prime} \mathrm{N} 134^{\circ} 41.34^{\prime} \mathrm{W}$, B. Bennett 00-291, 3 July 2000 (DAO); open dolomite delta, same locality, B. Bennett 00-293, 3 July 2000 (DAO); open slopes, moist areas, Wind River, Deception Mountain, $65^{\circ} 36.03^{\prime} \mathrm{N} 135^{\circ} 28.41^{\prime} \mathrm{W}, B$. Bennett $00-442$ and 00 275, 7 July 2000 (DAO); moderately steep southfacing slope, Bonnet Plume River, 6437'32'N 13317'20”'W, V. Loewen 99-32-97, 15 July 1999 (DAO); alpine slope - Dryas/forb/sedge, Upper Bonnet Plume River Drainage Site \#100, 64²0'20'N $132^{\circ} 15^{\prime} 28^{\prime \prime} \mathrm{W}, \mathrm{J}$. Staniforth 00-013, 5 July 2000 (DAO); convex lower ridge - dry, well drained rocky slope, Upper Bonnet Plume River Drainage Site \#132, $64^{\circ} 31^{\prime} 19^{\prime \prime N} 132^{\circ} 51^{\prime} 39^{\prime \prime} W$, J. Staniforth 00-039, 7 July 2000 (DAO).

Between latitudes $64^{\circ} \mathrm{N}$ and $66^{\circ} \mathrm{N}$ Cody (1996) knew this species only as far east as about $66^{\circ} 04^{\prime} \mathrm{N} 135^{\circ} 50^{\prime} \mathrm{W}$. The specimens cited above extend the known distribution about 50 kilometers to the northeast and about 200 kilometers to the southeast.

Carex magellanica Lam. ssp. irrigua (Wahlenb.) Hiit., Bog Sedge - YukON: in basin bog in old oxbow on Eagle River, Eagle Plains, $66^{\circ} 16^{\prime} \mathrm{N} 136^{\circ} 31^{\prime} \mathrm{W}, R$. Rosie 2140, 2141, 18 July 2000 (DAO).

Cody (1996) knew this species in the Territory north to about latitude $64^{\circ} \mathrm{N}$. The specimens cited above extend the known distribution about 280 kilometers to the north.

Carex media R.Br., Alpine Sedge - YuKON: mucky bank of tributary stream in gravels, Wind River, $65^{\circ}$ $46.36^{\prime} \mathrm{N} 135^{\circ} 10.71^{\prime} \mathrm{W}$, B. Bennett 00-129, 8 July 2000 (DAO).

The specimen cited above is from the only site between latitudes $64^{\circ}$ and $66^{\circ} \mathrm{N}$ east of the Dempster Hwy (Cody 1996).

Carex microglochin Wahlenb., Few-seeded Bog or Bristle Sedge - YuKON: in meadow near river amongst older Picea glauca forest with a little Populus balsamifera, Wind River Camp \#1, 64²40.39'N 134³5.96’W, B. Bennett 00-717, 2 July 2000 (DAO); silty mud on edge of lake, Wind River Camp \#2, $64^{\circ} 51.83^{\prime} \mathrm{N} 134^{\circ} 38.85^{\prime} \mathrm{W}$, B. Bennett 00-826, 4 July 2000 (DAO).

The specimens cited above are the only known collections between latitudes $64^{\circ} \mathrm{N}$ and $66^{\circ} \mathrm{N}$ (Cody 1996) about 180 kilometers east of a site adjacent to the Dempster Hwy.
Carex obtusata Liljeb., Blunt Sedge - Yukon: severly mounded valley floor wetland in undulating valley floor sedge meadow, Upper Bonnet Plume River Drainage Site \#142, 64²2'47”N 13207'52'W, J. Staniforth 00-127, 4-12 July 2000 (DAO).

The specimen cited above is the only collection between latitudes $64^{\circ}$ and $66^{\circ}$ east of the Dempster Hwy. The nearest collection to the southwest, just west of longitude $135^{\circ}$ is about 200 kilometers (Cody 1996).

Carex pachystachya Cham., Thick-headed Sedge YukON: St. Elias Trail, Kluane National Park, $60^{\circ} 18^{\prime} \mathrm{N} 137^{\circ} 03^{\prime} \mathrm{W}$, P. Caswell, PPC-2000-Y-310, 18 Aug. 2000 (DAO); wet lakeshore inlet of Caribou Creek to Caribou Lake, $60^{\circ} 32.0^{\prime} \mathrm{N} 134^{\circ} 15.9^{\prime} \mathrm{W}, S$. Withers SW00-168, 7 Aug. 2000 (DAO).

Cody (1996) knew this rare species in the Territory, southeast Kluane Park and just west of Watson Lake. The first collection cited above is from a site just northeast of the first Kluane Park collection and the second is intermediate between Watson Lake and Kluane Park.

Carex phaeocephala Piper, Dunhead Sedge - YukON: in wetland south of Squanga Lake, $60^{\circ} 26.20^{\prime} \mathrm{N} 133^{\circ}$ 35.24'W, R. Rosie 2171, 13 Aug. 2000 (DAO).

The specimen cited above is an extension of the known range in the Territory (Cody 1996) of about 190 kilometers east of a site adjacent to the Haines Hwy. just north of latitude $60^{\circ} \mathrm{N}$.

Carex rostrata Stokes - YUKON: slough in creek near camp, Dog Creek Camp, Vuntut National Park, $68^{\circ} 27.52^{\prime} \mathrm{N} 138^{\circ} 44.47^{\prime} \mathrm{W}$, B. Bennett 00-1169, 4 Aug. 2000 (DAO).

The specimen cited above is the northernmost yet found in the Territory (Cody 1996). It is an extension of the known range of about 125 kilometers north from a site adjacent to the Porcupine River.

Carex viridula Michx., Green Sedge - YUKON: along sandy-gravelly shore of small lake in uplands, Squanga Lake, $60^{\circ} 27^{\prime} \mathrm{N} 133^{\circ} 38^{\prime} \mathrm{W}, R$. Rosie 2172, 12 Aug. 2000 (DAO); among Salix at mouth of intermittent ephemeral creek, Nisutlin River Delta, 60¹3'11'N $132^{\circ} 31$ '23”W, B. Bennett 98-484, 28 July 1998 (DAO).

This is a rare species in the Territory (Douglas et al. 1981). The specimens cited above are from sites intermediate between Whitehorse and Watson Lake.

Carex williamsii Britt., William's Sedge - Yukon: silty seep on edge of river, Peel River Site \#1, $65^{\circ} 58.06^{\prime} \mathrm{N} 134^{\circ} 49.69^{\prime} \mathrm{W}$, B. Bennett 00-433, 10 July 2000 (DAO).

This is a rare species in the Territory (Douglas et al. 1981). The specimen cited above is an extension of the known range in the Territory of about 225 kilometers northeast of sites adjacent to the Dempster Hwy.

Eriophorum brachyantherum Trautv., Short-anthered Cotton-grass - YukON: in hummocky Picea/Salix forest near river, McClusky Lake, Wind River, $64^{\circ} 34.19^{\prime} \mathrm{N} 134^{\circ} 25.77^{\prime} \mathrm{W}$, B. Bennett 00-328, 2 July 2000 (DAO). 
The specimen cited above is an extension of the known range in the Territory of about 80 kilometers northeast of a site north of Mayo (Cody 1996).

Eriophorum callitrix Cham., Arctic Cotton-grass YUKON: steep solifluction slope in moist area, Dog Creek Camp, Vuntut National Park, 68 27.53'N 138 44.47'W, B. Bennett 00-1071, 2 Aug. 2000 (DAO).

Cody (1996) knew this species in the Territory west of longitude $135^{\circ} \mathrm{W}$ north to about $65^{\circ} 45^{\prime} \mathrm{N}$ and then disjunct to the Mt. Sedgwick area in the British Mountains. The specimen cited above is from a site about 40 kilometers southeast of Mt. Sedgewick.

Eriophorum scheuchzeri Hoppe, Scheuchzer's Cottongrass - YUKON: boggy tussock tundra near small pond, Wind River Camp \#2, 6451.83'N 134³8.85’W, B. Bennett 00-814, 4 July 2000 (DAO); silty seep at edge of river, Peel River Site \#1, 6558.06'N 13449.69'W, B. Bennett 00-403, 10 July 2000 (DAO); boggy area with open pools, Peel River, $66^{\circ} 00.36^{\prime} \mathrm{N} 134^{\circ} 43.19^{\prime} \mathrm{W}$, B. Bennett 00-464, 11 July 2000 (DAO).

Between latitudes $64^{\circ} \mathrm{N}$ and $67^{\circ} \mathrm{N}$ the only site known in the Territory to Cody (1996) was adjacent to the Upper Bonnet Plume River. The Wind River site is about 130 kilometers to the northwest.

Kobresia simpliciuscula (Wahlenb.) Mack., Simple Kobresia - YuKON: Wind River, 6448.46'N 134 41.34'W, B. Bennett 00-359, 3 July 2000 (DAO); riverbar, Wind River, $65^{\circ} 12.49^{\prime} \mathrm{N} 135^{\circ} 13.17^{\prime} \mathrm{W}, B$. Bennett 00-199, 5 July 2000 (DAO); hummocky Picea mariana site, Wind River, 64 $58.67^{\circ} \mathrm{N} 134^{\circ} 47.12^{\circ} \mathrm{W}$, B. Bennett 00-299, 4 July 2000 (B. Bennett Herbarium, photo DAO); dry tundra growing on bare solifluction ground, Vuntut National Park, 68 $25.45^{\prime} \mathrm{N} 138^{\circ} 41$. 45'W, B. Bennett 00-1051, 5 Aug. 2000 (DAO); open bare soil on solifluction plain, Dog Creek Ponds, Vuntut National Park, 68²6.37'N 138 45.12’W, B. Bennett 00-1053, 8 Aug. 2000 (DAO).

The first three specimens cited above are extensions of the known range in the Territory (Cody 1996) between latitudes $64^{\circ} \mathrm{N}$ and $66^{\circ} \mathrm{N}$ of about 175 kilometers east of the Dempster Hwy. The last two specimens cited above are intermediate between a site west of the Firth River and sites near the Northwest Territory border.

Scirpus caespitosus L. ssp. austriacus (Pallas) Asch. \& Graebn., Tufted Clubrush - YukON: wet area adjacent to stream in open dolomite delta, Wind River, 6448.46'N 134²1.34'W, B. Bennett 00-256, 3 July 2000 (DAO).

The specimen cited above is intermediate between a site adjacent to the Upper Bonnet Plume River and sites mapped by Cody (1996) adjacent to the Dempster Hwy.

\section{JUNCACEAE}

Juncus balticus Willd. var. littoralis Engelm., Baltic Rush - YUKON: in meadow along brook draining warm spring, McPherson Lake, 61 52'19'”N 129³6'34'W, R. Rosie 2092, 6 Sept. 2000 (DAO).

The specimen cited above is an extension of the known distribution in the Territory (Cody 1996) of about 150 kilometers east of a site near Ross River.
Juncus triglumis L. ssp. albescens (Lange) Hultén, Whitish Rush - YUKON: open solufluxion plains growing on bare soil, Dog Creek Ponds, Vuntut National Park, $68^{\circ} 26.37^{\prime} \mathrm{N} 138^{\circ} 26.37^{\prime} \mathrm{W}$, B. Bennett 00-934, 7 Aug. 2000 (DAO).

Cody (1996) knew this taxon north of latitude $66^{\circ} \mathrm{N}$ in the Territory from only three sites in the far northwest. The specimen cited above was found about 75 kilometers east and southeast from those locations.

\section{LILIACEAE}

Lloydia serotina (L.) Rchb., Alp Lily - YUKON: alpine slope just above treeline, Upper Bonnet Plume River Drainage Site \#103, 64²6'15'N 132 $15^{\circ}$ '47'W, J. Staniforth 00-018, 5 July 2000 (DAO).

The specimen cited above is from a site in the Territory (Cody 1996) about 85 kilometers southeast of one between the Wind and Bonnet Plume rivers.

Maianthemum dilatatum (A. Wood) Nels. \& Macbr., False Lily-of-the-valley

In Volume 6 of the Illustrated Flora of British Columbia (Douglas et al. 2001) this species was reported as occurring in the Yukon Territory. This was presumably based on the distribution map in the monograph of the genus Maianthemum (La Frankie 1986) where a triangle appeared in the extreme southwest of the Territory; however, the text says "along the Canadian coast as far north as northern British Columbia (Haines Road, Mile 45, Taylor 1552 (GH)). Based on lack of material evidence for its presence in the Yukon and probable error in plotting which led to the only Yukon report, this species should not yet be included in the Yukon Flora.

Streptopus amplexifolius (L.) DC. ssp. americanus (Schultes) A. \& D. Löve, Clasping Twistedstalk YUKON: along alpine brook, Crescent Lake, 60¹1'00’'N $131^{\circ} 15$ '30'W, R. Rosie 2118, 22 July 2000 (DAO).

Cody (1996) considered this taxon to be rare in the Territory north to about latitude $63^{\circ} \mathrm{N}$. The specimen cited above was found about 100 kilometers southeast of Johnson's Crossing.

Veratrum viride Ait. ssp. eschscholtzii (Gray) A. \& D. Löve, White Hellebore - YUKON: strongly mounded lower slope, Upper Bonnet Plume River Drainage Site \#155, 64'28'13'N 132 18 '33'W, J. Staniforth 00-150, 12 July 2000 (DAO).

The specimen cited above is the northernmost yet found in the Territory (Cody 1996). It was collected about 130 kilometers northeast of a site northeast of Mayo.

\section{IRIDACEAE}

Iris setosa Pallas ssp. interior (Anders.) Hultén, Wild Iris - YUKON: sand flats, highway crossing, Takhini River, W of Whitehorse, [60 $\left.51^{\prime} \mathrm{N} 135^{\circ} 45^{\prime} \mathrm{W}\right]$, V.C. Brink V51225, 6 July 1943 (UBC).

Douglas et al. (1981) considered this taxon rare in the Territory. Cody (1996) mapped two collections from near the Alaska border and one from the vicinity of Whitehorse. The specimen cited above was the basis of the Whitehorse dot that should have been about 35 kilometers to the northwest of Whitehorse adjacent to the Takhini River. 


\section{SAlicaCeaE}

Salix alaxensis (Anderss.) Cov. ssp. longistylis (Rydb.) Hultén, Feltleaf Willow - YuKON: river alder, Richardson Mts., 66 50'22'N 13456'56”'W, G. Brunner 26-00, 17 July 2000, (YUKH, photo DAO) (determined by G. Argus).

The specimen cited above is the first of this subspecies collected between latitudes $64^{\circ} \mathrm{N}$ and $67^{\circ} \mathrm{N}$. The nearest site known to Cody (1996) is about 80 kilometers to the northwest.

Salix arbusculoides Anderss., Little-tree Willow YUKON: river alder, Richardson Mts., 6650'22"N 13456'56”'W, G. Brunner 25-00, 17 July 2000 (DAO) (determined by G. Argus).

Cody et al. (2002) reported this species from adjacent to the Peel River about 120 kilometers to the south of the specimen cited above. Cody (1996) mapped a site about 120 kilometers to the northwest.

Salix arctica Pall., Arctic Willow - YuKON: strongly mounded lower slope, moist hummocky tundra, Upper Bonnet Plume River Drainage Site \#153, 64²8'21'N $132^{\circ} 19^{\prime} 16^{\prime}$ W, J. Staniforth 00-155A, 12 July 2000 (DAO) (determined G. Argus).

The specimen cited above is the easternmost yet found between latitudes $64^{\circ} \mathrm{N}$ and $66^{\circ} \mathrm{N}$. It is from a site about 90 kilometers southeast a site mapped by Cody (1996).

Salix arctophila Cockerell, Northern Willow - YuKON: severely mounded valley floor wetland in undulating valley floor sedge meadow, Upper Bonnet Plume River Drainage Site, 6422'47'N 132 07'52'W, J. Staniforth 00-126 and 00-135, 4-12 July 2000 (DAO) (determined by G. Argus).

Cody (1996) knew this species in the Territory from adjacent to the Arctic Coast, the northern Richardson Mts. and from a site at the north end of the Canol Road. Cody et al. (2001) reported it from the Patrol Range in the Ogilvie Mts. The specimens cited above were from a site about 175 kilometers northwest of the Canol Road site.

Salix commutata Bebb, Variable Willow - YUKON: in disturbed site in alpine, Crescent Lake, $60^{\circ} 11^{\prime} 00^{\prime \prime} \mathrm{N}$ 131 15 '30”W, R. Rosie 2125, 21 July 2000 (DAO) (determined by G. Argus).

Cody (1996) knew this species in the Territory only as far north as the north end of the North Canol Road and as far east as about longitude $129^{\circ} \mathrm{W}$. The nearest site to the one reported above is about 175 kilometers to the northwest adjacent to the South Canol Road.

Salix fuscescens Anderss., Alaska Bog Willow - YukON: tussock tundra, Wind River Camp \#2, 64 ${ }^{\circ} 51.83^{\prime} \mathrm{N}$ $134^{\circ} 38.85^{\prime} \mathrm{W}$, B. Bennett 00-825, 4 July 2000 (DAO) (determined by G. Argus).

The specimen cited above is only the second known in the Territory south of latitude $66^{\circ} \mathrm{N}$ (Cody 1996). It is from about 175 kilometers east of a site adjacent to the Dempster Hwy.

Salix hastata L., Halbred Willow - YUKON: established riparian forest, Illytd Creek confluence with

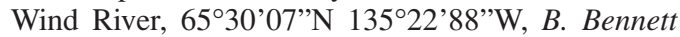
00-437, 6 July 2000 (DAO); Betula/Salix/Alnus upland esker in gravelly soil, Wind River Camp \#6, 6540.46'N 135¹1.76'W, B. Bennett 00-858A, 00-144, 7 July 2000 (DAO) (determined by G. Argus).

The specimens cited above are the first known to Cody (1996) between latitudes $64^{\circ} \mathrm{N}$ and $66^{\circ} \mathrm{N}$ east of the Dempster Hwy. It is about 75 kilometers south of a site north of latitude $66^{\circ} \mathrm{N}$.

Salix niphoclada Rydb., (S. brachycarpa Nutt. ssp. niphoclada (Rydb.) Argus), Barren-ground Willow - YUKON: tussock tundra, Wind River Camp \#2, 64 $51.83^{\prime} \mathrm{N}$ $134^{\circ} 38.85^{\prime} \mathrm{W}$, B. Bennett 00-830, 4 July 2000 (DAO); riverbar, east bank near confluence of Royal Creek,

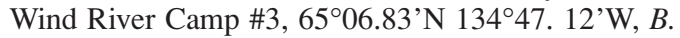
Bennett 00-194, 4 July 2000 (DAO); talus slope near river, Deception Mountain, Wind River, $65^{\circ} 36.03^{\prime} \mathrm{N}$ $135^{\circ} 28.44^{\prime} W$, B. Bennett 00-414, 7 July 2000 (DAO); loose talus at base of steep active scree slope, junction of Wind and Peel rivers, $65^{\circ} 50.48^{\prime} \mathrm{N} 135^{\circ} 18.25^{\prime} \mathrm{W}$, B. Bennett 00-808, 8 July 2000 (DAO) (determined by G. Argus).

The specimens cited above are the first records in the Territory (Cody 1996) from the area east of the Dempster Hwy.

Salix polaris Wahlenb., Snow-bed Willow - YukON: undulating upper slope, Upper Bonnet Plume River Drainage Site \#125, 64²' $45^{\circ}$ 'N 132 50 ' $48^{\prime \prime}$ 'W, $J$. Staniforth 00-100, 8 July 2000 (DAO); strongly mounded lower slope, Upper Bonnet Plume River Drainage Site \#153, 64²8’21'N 132 $12^{\circ} 16^{\prime}$ 'W, J. Staniforth 00-155B, 12 July 2000 (DAO); moist hummocky tundra, Upper Bonnet Plume River Drainage Site \#118, 6424'12.6”'N 13207'4'”, J. Staniforth 00-083, 7 July 2000 (DAO) (determined by G. Argus).

The specimens cited above are the easternmost yet known to Cody (1996) between latitudes $64^{\circ} \mathrm{N}$ and $66^{\circ} \mathrm{N}$, about 110 kilometers east of the nearest known site.

Salix pseudomonticola Ball, (S. monticola sensu Cody 1996), Mountain Willow - YUKON: concave lower slope, spruce adjacent to river, Upper Bonnet Plume River Drainage, $64^{\circ} 22^{\prime} 26^{\prime}$ N $132^{\circ} 46^{\prime} 40^{\prime} \mathrm{W}$, J. Staniforth 00-139, 10 July 2000 (DAO).

Cody et al. (2002) extended the known range of this species in the Territory (Cody 1996) about 275 kilometers north of a site in the vicinity of Mayo. The specimen cited above is an extension of the known range of about 175 kilometers northeast of Mayo.

Salix richardsonii Hook., (S. lanata L. ssp. richardsonii (Hook.) Skvortsov), Richardson's Willow - YUKON: valley floor, riparian zone of small alpine creek, Upper Bonnet Plume River Drainage, 64³0'13'N 13301' 38 "W, J. Staniforth 00-148, 11 July 2000 (DAO); in hummocky Picea/Salix forest near river, McClusky Lake, Wind River, $64^{\circ} 34.19^{\prime} \mathrm{N} 134^{\circ} 25.77^{\prime} \mathrm{W}, \mathrm{B}$. Bennett 00-376, 2 July 2000 (DAO); bank of river, Wind River Camp \#2, 64 $45.05^{\prime} \mathrm{N} 134^{\circ} 38.75^{\prime} \mathrm{W}$, B. Bennett 00-835, 3 July 2000 (DAO) (determined by G. Argus). 
The specimens cited above are an extension of the known range in the Territory (Cody 1996) of about 100 kilometers northwest of a site adjacent to the Upper Bonnet Plume River.

Salix rotundifolia Trautv. ssp. rotundifolia, Roundleaf Willow - YUKON: growing amongst large black lichen covered talus on alpine barrens, "Selaginella Summit Site", 68³0'23'N 138 45'18'W, B. Bennett 00-1122, 4 Aug. 2000 (DAO) (determined by G. Argus).

Cody (1996) knew this rare species in the Territory, from three sites in the British Mountains and one in the southwest. The specimen cited above is an extension of the known range of about 75 kilometers southeast of a site east of the Firth River.

\section{Betulaceae}

Alnus crispa (Drylander ex Ait.) Pursh ssp. crispa, Green Alder - YUKON: steep talus slope, Little Wind River/Wind River confluence, $65^{\circ} 22.89^{\prime} \mathrm{N} 135^{\circ} 26.1^{\prime} \mathrm{W}$, B. Bennett 00-837, 5 July 2000 (DAO).

The specimen cited above is the first reported from the Wind River, it is however known from the Bonnet Plume River to the southeast and adjacent to the Peel River to the northeast and northwest (Cody 1996).

Alnus incana (L.) Moench ssp. tenuifolia (Nutt.) Breitung, Grey Alder - YuKon: lush Picea glaucal Alnus incana established riparian thicket, Wind River

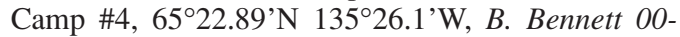
167, 5 July 2000 (DAO).

The specimen cited above is only the second record from between latitudes $64^{\circ} \mathrm{N}$ and $67^{\circ} \mathrm{N}$ east of the Dempster Hwy. (Cody 1996). The other record is from just south of the Peel River about 75 kilometers to the northeast.

Betula neoalaskana Sarg., Alaska Birch - YUKON: Betula neoalaskana/Salix scouleriana/S. bebbiana/ Alnus crispa upland esker in gravelly soil, Wind River Camp \#6, 6540.46'N 135¹1.76'W, B. Bennett 00252, 7 July 2000 (B. Bennett Herbarium, photo DAO).

The specimen cited above is the first record between latitudes $64^{\circ} 15^{\prime} \mathrm{N}$ and $66^{\circ} \mathrm{N}$ (Cody 1996). The nearest site is just north of latitude $66^{\circ} \mathrm{N}$ about 80 kilometers to the north.

Betula occidentalis Hook., Water Birch - YUKON: forest site, amongst Picea glauca, Vuntut National Park, 68 25'45'N 138 41'27'W, B. Bennett 00-1127, 5 Aug. 2000 (B. Bennett Herbarium, photo DAO).

The specimen cited above is the northernmost yet found in the Territory (Cody 1996). The nearest known site is about 60 kilometers to the southwest.

Betula papyrifera Marsh., Paper Birch - YUKON: Wind River, half way between Little Wind River and Illytd Creek, 652 $7^{\prime} \mathrm{N} 135^{\circ} 24^{\prime} \mathrm{W}$, B. Bennett 00-436, 6 July 2000 (B. Bennett Herbarium, photo DAO).

The specimen cited above of this only occassionally found species is the northernmost yet found in the Territory (Cody 1996). The nearest known site is adjacent to the southern Dempster Hwy. about 200 kilometers to the southwest.

\section{Santalaceae}

Comandra umbellata (L.) Nutt. ssp. pallida (A.DC.) Piehl, Pale Comandra - YUKON: exposed lakeshore,
Kluane Lakeshore near Cultus Bay, 6109.7'N $138^{\circ} 26^{\prime}$ 'W, S. Withers SW00-089, 22 July 2000 (DAO).

This is only the fourth known site in the Territory of this species, which was considered rare by Douglas et al. (1981). The nearest known site was at the south end of Kluane Lake (Cody 1996).

\section{Polygonaceae}

Polygonum achoreum Blake, Striate Knotweed YuKON: Haines Junction, 6044'N 137³1'W, $P$. Caswell PPC-2000-Y-441, 29 Aug. 2000 (DAO).

This is not a common weed in the Territory. The nearest sites known to Cody (1996) are near the south end of Kluane Lake and in the vicinity of Whitehorse.

Polygonum aviculare L., Common Knotweed YUKON: former experimental farm NW of Haines Junction, $60^{\circ} 46^{\prime} \mathrm{N} 137^{\circ} 35^{\prime} \mathrm{W}, P$. Caswell PPC-2000Y-441, 18 July 2000 (DAO).

This is not a common introduced weed in the Territory. The nearest site known to Cody (1996) is in the vicinity of Johnson's Crossing about 250 kilometers to the east.

Rumex acetosa L. ssp. alpestris (Scop.) A. Löve, Green Sorrel - YukON: along edge of creek in valley wetland, Crescent Lake, 60 $13^{\circ} 00^{\prime \prime} \mathrm{N} 131^{\circ} 12^{\prime} 30^{\prime}$ 'W, R. Rosie 2122, 21 July 2000 (DAO).

This taxon is rare in the Territory (Cody 1996). The nearest site to the one listed above is about 150 kilometers to the east, just west of Watson Lake.

\section{Caryophyllaceae}

Cerastium arvense L., Field Chickweed - YuKOn: disturbed meadow, Wind River Camp \#2, 64 ${ }^{\circ} 45.05^{\prime} \mathrm{N}$ $134^{\circ} 38.75^{\prime}$ W, B. Bennett 00-833, 3 July 2000 (DAO).

This is the northernmost specimen yet found in the Territory (Cody 1996). The nearest site to that listed above is from near the junction of the Klondike and Dempster highways about 225 kilometers to the southwest.

Minuartia dawsonensis (Britt.) House, Rock Sandwort - YUKON: vicinity of Snowdrift Camp, Vuntut National Park, $68^{\circ} 21.4^{\prime} \mathrm{N} 139^{\circ} 13.1^{\prime} \mathrm{W}$, P. Caswell $P P C$-2000-Y-098, 19 June 2000 (DAO).

The specimen cited above is the northernmost yet found in the Territory (Cody 1996). It is about 270 kilometers northwest of a site north of latitude $66^{\circ} \mathrm{N}$.

Minuartia elegans (Cham. \& Schlecht.) Schlecht., Northern Sandwort - YUKON: open riverbar in silt, Illytd Creek confluence with Wind River, $65^{\circ} 30.07^{\prime} \mathrm{N}$ $135^{\circ} 22.88^{\prime} \mathrm{W}$, B. Bennett 00-110, 6 July 2000 (B. Bennett Herbarium, photo DAO); riverbar, Wind

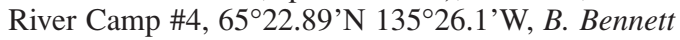
00-303, 5 July 2000 (DAO); tussock tundra, Wind

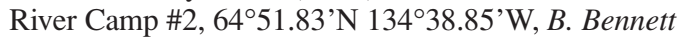
00-820, 4 July 2000 (B. Bennett Herbarium, photo DAO); alpine tundra just above treeline, Upper Bonnet

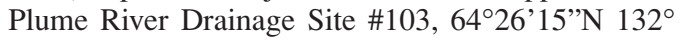
15'47'W, J. Staniforth 00-024, 5 July 2000 (DAO).

The specimens cited above extend the known distribution in the Territory east about 225 kilometers between latitudes $64^{\circ}$ and $66^{\circ} \mathrm{N}$ from a site about longitude $136^{\circ} 30^{\prime} \mathrm{W}$ (Cody 1996). 
Minuartia obtusiloba (Rydb.) House, Alpine Sandwort - YuKon: moist wooded slope, Royal Creek, Wind River, $65^{\circ} 06.83^{\prime} \mathrm{N} 134^{\circ} 47.12^{\prime} \mathrm{W}$, B. Bennett 00-219, 4 July 2000 (DAO).

The specimen cited above is an extension of the known range in the Territory of about 150 kilometers east of a site adjacent to the Blackstone River (Cody 1996).

Minuartia yukonensis Hultén, Yukon Stitchwort YUKON: talus slope near river, Deception Mountain,

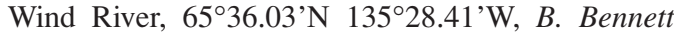
00-279, 7 July 2000 (B. Bennett Herbarium, photo DAO).

The specimen cited above is the only record of this species between latitudes $64^{\circ} \mathrm{N}$ and $66^{\circ} \mathrm{N}$ east of the Dempster Hwy. The nearest site to this locality is about 75 kilometers to the northwest (Cody et al. 2000).

Silene acaulis L. ssp. acaulis, Moss Campion - YuKON: open Picea glauca forest, Wind River Camp \#1, $64^{\circ} 34.43^{\prime} \mathrm{N} 134^{\circ} 28.88^{\prime} \mathrm{W}, B$. Bennett 00-268, 2 July 2000 (DAO).

The specimen cited above, which is the first known from the drainage of the Wind River is an extension of the known range in the Territory (Cody 1996) of about 50 kilometers north of a site north of latitude $64^{\circ} \mathrm{N}$.

Silene involucrata (Cham. \& Schlecht.) Bocquet ssp. involucrata, Arctic Campion - YUKON: talus at edge of river, Wind River, $65^{\circ} 12.49^{\prime} \mathrm{N} 135^{\circ} 12.9^{\prime} \mathrm{W}$, B. Bennett 00-138, 5 July 2000 (DAO).

The specimen cited above is the first known in the Territory from the area between latitude $64^{\circ} \mathrm{N}$ and the Peel River east of the Dempster Hwy.

Silene taimyrensis (Tolmatchev) Bocquet, Taimyr Campion - Yukon: loose talus at base of steep active shale scree slope junction of Wind and Peel rivers, $65^{\circ} 50.48^{\prime} \mathrm{N} 135^{\circ} 18.25^{\prime} \mathrm{W}$, B. Bennett 00-811, 8 July 2000 (DAO).

The specimen cited above is the northernmost yet known in the Territory (Cody 1996). It is an extension of the known range of about 100 kilometers to the northwest from a site adjacent to the Bonnet Plume River.

Spergularia rubra (L.) J. \& C. Presl, Purple Sand Spurry - YUKON: along dirt mining exploration road below treeline, Crescent Lake, 60 ${ }^{\circ} 10^{\prime} 03^{\prime \prime} \mathrm{N} 131^{\circ} 06^{\prime}$ 55"W, R. Rosie 2104, 24 July 2000 (DAO).

The specimen of this introduced species cited above is an extension of the known range in the Territory (Cody 1996) of about 140 kilometers west of a site adjacent to Watson Lake and is an equal distance northwest to a site adjacent to the South Canol Road.

Stellaria borealis Bigelow, Boreal Starwort - YUKON: disturbed area, Wind River Camp \#2, 64 ${ }^{\circ} 45.05^{\prime} \mathrm{N}$ $134^{\circ} 38.75^{\prime} \mathrm{W}$, B. Bennett 00-189, 3 July 2000 (DAO); in outwash delta containing round balls of clay, falcon site between Camp \#10 and Taco Bar, $65^{\circ} 55^{\prime} \mathrm{N}$ $134^{\circ} 15^{\prime} \mathrm{W}$, B. Bennett 00-387, 12 July 2000 (DAO).

The specimens cited above are extensions of the known range in the Territory (Cody 1996) of about 100 kilometers northeast from a site north of Mayo and 125 kilometers east of a site adjacent to the Dempster Hwy.
Stellaria longifolia Muhl., Long-leaved Chickweed YuKON: hydric tussock tundra by rivulets, Vuntut National Park, $68^{\circ} 30.14^{\prime} \mathrm{N} 138^{\circ} 45.45^{\prime} \mathrm{W}$, B. Bennett 00-958, 4 Aug. 2000 (DAO); rich late snowmelt meadow beside Dog Creek, Vuntut National Park, $68^{\circ} 29.14^{\prime} \mathrm{N} 138^{\circ} 50.35^{\prime} \mathrm{W}$, B. Bennett 00-955, 4 Aug. 2000 (DAO); on lake edge with Galium trifidum, $68^{\circ} 24.24^{\prime} \mathrm{N} 138^{\circ} 37.58^{\prime} \mathrm{W}$, B. Bennett 00-986, 5 Aug. 2000 (DAO); in basin bog in old oxbow on Eagle River, Eagle Plains, R. Rosie 2133, 18 July 2000 (DAO); Larix laricina/Picea mariana/Carex medial Eriophorum vaginatum marsh, Peel River Camp \#10 between Snake and Bonnet Plume rivers, $65^{\circ} 57.61^{\prime} \mathrm{N}$ $134^{\circ} 25.68^{\prime} \mathrm{W}$, B. Bennett 00-700, 12 July 2000 (DAO).

The first three specimens cited above are the northernmost yet found in the Territory (Cody 1996). The last two specimens cited above are the first known between latitudes $64^{\circ} \mathrm{N}$ and $67^{\circ} \mathrm{N}$ east of the Dempster Hwy.

Stellaria media (L.) Vill., Chickweed - Yukon: flower bed at gas station, Haines Junction, $60^{\circ} 44^{\prime} \mathrm{N}$ 137³1'W, P. Caswell PPC-2000-Y-483, 26 Aug. 2000 (DAO).

The specimen of this introduced species cited above is intermediate between a site northwest of Kluane Lake and the vicinity of Whitehorse (Cody 1996; Cody et al. 2001).

\section{Ceratophyllaceae}

Ceratophyllum demersum L., Hornwort - YuKON: floating in shallows along shore of Red River Lake, $61^{\circ} 00.43^{\prime} \mathrm{N} 132^{\circ} 21.30^{\prime} \mathrm{W}, R$. Rosie 2183, 16 June 2000 (DAO).

Cody (1996) knew this circumpolar species in the Territory only from the Old Crow Flats and a site southeast of Mayo. Cody et al. (2000) reported a third area from Lee's Lake in the extreme southeast. The specimen cited above is from a site intermediate between the site southeast of Mayo and Lee's Lake.

\section{RANUNCULACEAE}

Aconitum delphinifolium DC. ssp. paradoxum (Rchb.) Hultén, Mountain Monkshood - YUKON: moist draw near spring near summit, White Mountain Summit, $60^{\circ} 18.36^{\prime} \mathrm{N} 133^{\circ} 57.24^{\prime} \mathrm{W}$, B. Bennett 00-590, 30 July 2000 (B. Bennett Herbarium, photo DAO).

This taxon is infrequent in the south of the Territory (Cody 1996). The nearest site to the one listed above is about 115 kilometers to the north.

Anemone multifida Poir., Cut-leaf Anemone - YUKON: steep calcareous slope forming moist caves with talus, Wind River, Royal Creek, $65^{\circ} 06.83^{\prime} \mathrm{N} 135^{\circ} 06.43^{\prime} \mathrm{W}$, B. Bennett 00-265, 3 July 2000 (DAO).

The specimen cited above is the northernmost yet found in the Territory (Cody 1996). The nearest site is about 140 kilometers to the south, just south of latitude $64^{\circ} \mathrm{N}$.

Aquilegia formosa Fisch. ex DC., Western Columbine - YUKON: along dirt mining exploration road below treeline, Crescent Lake, 60 $10^{\circ} 40^{\prime \prime} \mathrm{N} 131^{\circ} 10^{\prime} 00^{\prime \prime} \mathrm{W}$, R. Rosie 2121, 21 July 2000 (DAO).

This species was considered rare in the Territory by Douglas et al. (1981). The specimen cited above is the east- 
ernmost yet found in the Territory (Cody 1996). The nearest site is about 180 kilometers to the northwest adjacent to the South Canol Road.

Delphinium glaucum S. Wats., Tall Larkspur - YUKON: open Picea glauca forest on old river terrace, Wind River Camp \#6, 6540.46’N 135'11.76'W, B. Bennett 00-861, 7 July 2000 (DAO); riparian Picea glaucal Populus balsamifera/Alnus incana forest, Wind River, Deception Mountain, 65³6.03'N 135²8.41'W, B. Bennett 00-444, 7 July 2000 (DAO).

The only site between latitudes $64^{\circ} \mathrm{N}$ and $66^{\circ} \mathrm{N}$ east of the Dempster Hwy. known to Cody (1996) was in the headwaters of the Bonnet Plume River. The nearest sites to those listed above are about 80 kilometers to the northwest.

Ranunculus aquatilis L. var. eradicatus Laest., White Water Buttercup - YUKON: in shallow water, WNW side of Trout Lake, Ivvavik National Park, 68 49'27'’ 13845'8'W, J. M. Line 2000-15, 28 July 2000 (DAO).

The specimen cited above is the northernmost yet found in the Territory (Cody 1996). It is a range extension of about 60 kilometers from just north of longitude $68^{\circ} \mathrm{N}$.

Ranunculus eschscholtzii Schlecht., Subalpine Buttercup - YUKON: strongly mounded graminoid/moss/ lichen pediment with frost boils, Upper Bonnet Plume River Drainage Site \#131, 64³1'19'” 132 51'39'”, J. Staniforth 00-089, 4-12 July 2000 (DAO); alpine meadow beside lake, Beavercrow Ridge, $60^{\circ} 18.38^{\prime} \mathrm{N}$ 12434.834'W, B. Bennett 98-655, 17 Aug. 1998 (DAO).

The first specimen cited above is an extension of the known range in the Territory (Cody 1996) of about 100 kilometers from a site just north of latitude $64^{\circ} \mathrm{N}$; the second specimen is an extension of the known range of about 200 kilometers southeast of a site just west of longitude $127^{\circ} \mathrm{W}$.

Ranunculus flammula L., Creeping Spearwort YUKON: in wetland at west end of Trout Lake, $68^{\circ}$ 49'27'N 138 45'08'W, J. M. Line 2000-05, 25 July 2000 (DAO); along shoreline, Trout Lake, 6850’ N $138^{\circ} 45^{\prime}$ W, J. M. Line 2000-1W, 23 July 2000 (DAO).

The specimens cited above are the northernmost yet found in the Territory (Cody 1996). They are an extension of the known range of about 480 kilometers from a site adjacent to the southern Dempster Hwy.

Ranunculus pedatifidus Sm. ssp. affinis (R.Br.) Hultén, Birdfoot Buttercup - YUKON: wet area near caribou fence, vicinity of Snowdrift Camp, Vuntut National Park, 68²1.4'N 139¹3.1'W, P. Caswell PPC-2000$Y$-137, (Kluane National Park Herbarium, photo DAO).

Cody (1996) knew this species in the Territory west of longitude $136^{\circ} 45^{\prime} \mathrm{W}$ north to latitude $64^{\circ} \mathrm{N}$ and then disjunct to only two sites east of longitude $139^{\circ} \mathrm{W}$ and north of $68^{\circ} \mathrm{N}$.

Thalictrum alpinum L., Alpine Meadow Rue - YUKON: in moist meadows in valley near Rudy Lakes, $60^{\circ} 13^{\prime} 00^{\prime \prime N} 131^{\circ} 12^{\prime} 30^{\prime} \mathrm{W}$, R. Rosie 2123, 23 July 2000 (DAO).

The specimen cited above is an extension of the known range in the Territory (Cody 1996) of about 175 kilometers to the southeast from a site adjacent to the South Canol Road.
Thalictrum sparsiflorum Turcz. ssp. richardsonii (Gray) Cody, Few-flowered Meadowrue - YuKON: riparian area amongst shrub, Peel River, 65 $57.27^{\prime} \mathrm{N}$ $134^{\circ} 38.5^{\prime} \mathrm{W}$, B. Bennett 00-399, 11 July 2000 (DAO).

The specimen cited above is an extension of the known range in the Territory (Cody 1996) of about 60 kilometers from a site adjacent to the Bonnet Plume River. To the north the nearest sites known are adjacent to the Porcupine River.

\section{Brassicaceae (Cruciferae)}

Arabis boivinii G. A. Mulligan, Boivin's Rockcress YUKON: old Experimental Farm (Warden HQ), NW of Haines Junction, 6046’N $137^{\circ} 35^{\prime} \mathrm{W}, P$. Caswell PPC-2000-Y-213, 10 July 2000 (Kluane National Park Herbarium, photo DAO).

Cody et al. (2001) reported this species new to the Territory on the basis of collections from Kathleen Lake and the Dezadeash Camp Site to the southeast. The specimen cited above from about 40 kilometers to the northwest is only the third collection of this rare species in the Yukon.

Arabis codyi G. A. Mulligan, Cody's Rockcress YuKON: route to Martha Black Peak, Kluane National Park, 6041'N 137³3'W, P. Caswell PPC-2000-Y-184, 2 Aug. 2000 (DAO) (determined by G. A. Mulligan).

The specimen cited above is only the second known record in the Territory. The type specimen was collected at the Kaskawulsh Nunatak west of Kluane Lake about 20 kilometers to the southwest by D. F. and B. M. Murray in 1965. To the west it is known in the Wrangell-St. Elias National Park and Preserve in Alaska at $61^{\circ} 01.00^{\prime} \mathrm{N} 141^{\circ} 53.18^{\prime} \mathrm{W}$, M. B. Cook 9444 (DAO).

Arabis holboellii Hornem. var. retrofracta (Grah.) Rydb., Holboell's Rockcress - YuKON: Alsek Trail beyond Serpentine Creek, 6043'N 139 $46^{\circ} \mathrm{W}, P$. Caswell PPC-2000-Y-211, 9 July 2000 (DAO) (determined by G. A. Mulligan).

This species was known to Cody (1996) to be frequent in the Territory north to latitude $64^{\circ} \mathrm{N}$. The specimen cited above is an extension of about 60 kilometers west into Kluane National Park from sites adjacent to the Alaska Hwy.

Arabis kamtschatica (Fisch. ex DC.) Ledeb., Lyreleaved Rockcress - YUKON: valley floor, moist shrub/ graminoid/moss, Upper Bonnet Plume River Drainage Site \#114, 64²4'51'”N 132 23'W, J. Staniforth 0064, 6 July 2000 (DAO); on gravelbar of Caribou River, $66^{\circ} 15.41^{\prime} \mathrm{N} 135^{\circ} 31.28^{\prime} \mathrm{W}, R$. Rosie 2134, 15 July 2000 (DAO) (determined by G. A. Mulligan).

The first specimen cited above is an extension of the known range in the Territory (Cody 1996) of about 140 kilometers northeast of a site northeast of Mayo. The second specimen is from a site intermediate between sites just north of latitude $65^{\circ} \mathrm{N}$ adjacent to the Dempster Hwy. and north of latitude $65^{\circ} 15^{\prime} \mathrm{N}$.

Cardamine umbellata Greene (C. oligosperma Nutt. ssp. kamtschatica (Regel) Cody), Little Western Bittercress - YUKON: slough off Dog Creek, Vuntut National Park, 68²7.53'N $138^{\circ} 44.47^{\prime}$ W, B. Bennett 00-991, 6 Aug. 2000 (DAO). 
The specimen cited above is an extension of the known range in the Territory (Cody 1996) of about 450 kilometers to the north of a site adjacent to the Dempster Hwy.

Descurainia sophioides (Fisch.) O.E. Schulz, Northern Tanseymustard - YUKON: loose talus at base of steep active shale scree slope, junction of Wind and Peel rivers, Camp \#7, 65 $50.48^{\prime} \mathrm{N} 135^{\circ} 18.25^{\prime} \mathrm{W}$, B. Bennett 00-800, 8 July 2000 (B. Bennett Herbarium, photo DAO); open recently flooded riverbar, Peel River, $65^{\circ} 55.97^{\prime} \mathrm{N} 135^{\circ} 03^{\prime} \mathrm{W}$, B. Bennett 00-100, 9 July 2000 (B. Bennett Herbarium, photo DAO).

The specimens cited above are from sites intermediate between a site adjacent to the Dempster Hwy. (Cody 1996) and a site adjacent to the Snake River (Cody et al. 2001).

Draba albertina Greene, Slender Draba or Whitlowgrass - YUKON: undulating upper slope, small sedge meadow alongside seepage stream, Upper Bonnet Plume River Drainage Site \#138, 6432'31'”N 131 ${ }^{\circ}$ 29'8'W, J. Staniforth 00-114, 9 July 2000 (DAO); St. Elias Trail, Kluane National Park, $60^{\circ} 18^{\prime} \mathrm{N} 137^{\circ} 03^{\prime} \mathrm{W}$, P. Caswell PPC-2000-Y-335, 1 July 2000 (DAO) (determined by G. A. Mulligan).

The first specimen cited above is an extension of this rare species in the Territory (Cody 1996) of about 200 kilometers to the north from a site adjacent to the North Canol Road. The second specimen is the southernmost yet found in the Territory and is from a site about 50 kilometers southeast of sites near Haines Junction.

Draba borealis DC., Northern Draba - YUKON: moist hummocky tundra, undulating lower slope, Upper Bonnet Plume River Drainage Site \#109, 64²8'10'N $132^{\circ} 04^{\prime} 45^{\prime \prime W}, J$. Staniforth 00-004, 5 July 2000 (DAO); trailside beside ATV track, Wind River Camp \#2, 644․ $45.05^{\prime} \mathrm{N} 134^{\circ} 38.75^{\prime} \mathrm{W}$, B. Bennett 00-246, 3 July 2000 (DAO) (determined by G. A. Mulligan).

The specimens cited above are an extension of the known distribution in the Territory (Cody 1996) of about 175 kilometers to the northeast and about 100 kilometers north from a site northeast of Mayo.

Draba cana Rydb., Lance-leaved Whitlow-grass YUKON: in calcareous talus near summit, east bank near confluence of Royal Creek, Wind River Camp \#3, $65^{\circ} 06.83$ 'N $135^{\circ} 06.43^{\prime} \mathrm{W}$, B. Bennett 00-159, 3 July 2000 (DAO) (determined by G. A. Mulligan).

The specimen cited above is an extension of the known range in the Territory (Cody 1996) of about 150 kilometers east of sites adjacent to the Dempster Hwy. and north of sites just south of latitude $64^{\circ} \mathrm{N}$.

Draba cinerea Adams - YUKON: subalpine meadow with Vaccinium caespitosum on mesic slope with Pinus contorta, Abies lasiocarpa and Alnus incana, Kotaneelee Range, 60¹4'31'N 124'07'19'W, B. Bennett 98-598, 19 June 1998 (B. Bennett Herbarium, photo DAO); windblown ridge, submesic, rocky, Kotaneelee Range, 60³'08'N 12406'36'W, B. Bennett 98047, 20 June 1998 (B. Bennett Herbarium, photo DAO) (determined by G. A. Mulligan).
The specimens cited above are an extension of the known range in the Territory of about 190 kilometers east of a site west of longitude $127^{\circ} \mathrm{W}$ (Cody 1996).

Draba incerta Payson, Yellowstone Whitlow-grass YUKON: in dry Dryas/lichen on mountain top, Richardson Mts., 66 $38^{\circ} \mathrm{N} 135^{\circ} 47^{\prime} \mathrm{W}, R$. Rosie 2137, 11 July 2000 (DAO); upper talus slope in alpine, Deception Mtn., Wind River, 65'36.03'N $135^{\circ} 28.41^{\prime} \mathrm{W}, B$. Bennett 00-415A, 7 July 2000 (DAO) (determined by G. A. Mulligan).

The specimens cited above are from about 75 kilometers northwest and southwest of a site known to Cody (1996) just north of latitude $66^{\circ} \mathrm{N}$.

Draba kananaskis G. A. Mulligan, Longstalk Whitlowgrass (Figure 3) - YUKON: moist draw east of Dog Creek Camp, $68^{\circ} 27.53^{\prime} \mathrm{N} 138^{\circ} 44.47^{\prime} \mathrm{W}$, B. Bennett 00-994, 4 Aug. 2000 (DAO) (determined by G. A. Mulligan).

The specimen cited above is a new record for the Yukon Territory. This is an extension of the known range of about 900 kilometers north of sites in Wrangell-St. Elias National Park and Preserve in southeastern Alaska. A previous record (Cody \& Ginns 33149, 4 July 1984, from the Ogilvie Mts.) orginally identified as $D$. kananakis by Mulligan was revised by him to D. longipes in 1986 .

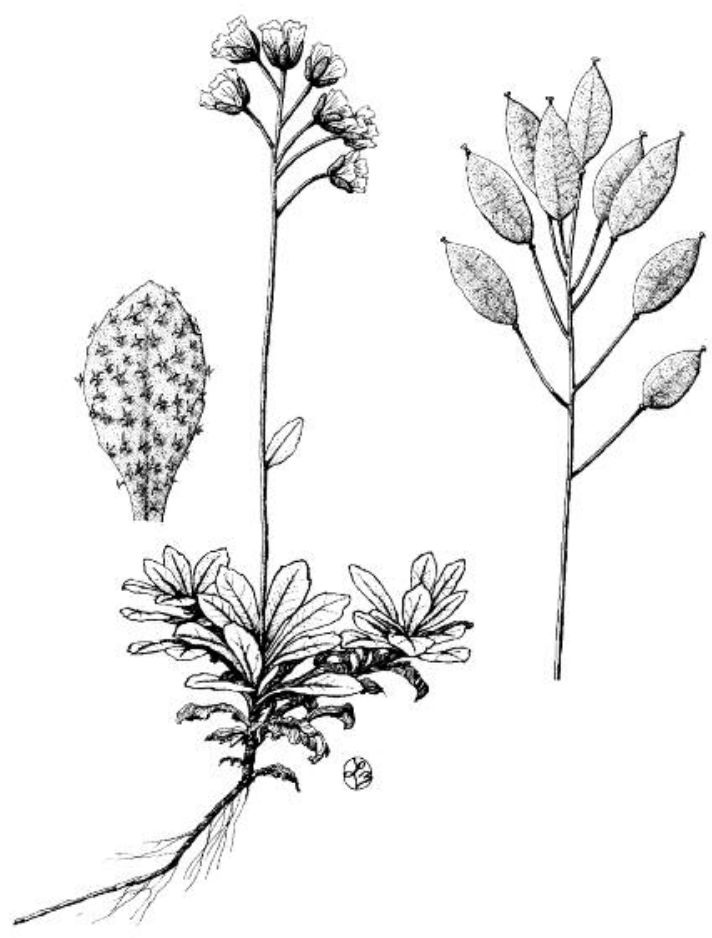

Figure 3. Draba kananaskis G. A. Mulligan, Longstalk Whitlow-grass (drawn by Lee Mennell). 
Draba macounii O.E. Schulz, Macoun's Draba or Whitlow-grass - YUKON: undulating upper talus slope, Upper Bonnet Plume River Drainage Site \#117, 64'24'27'N 132 $08^{\circ} 7^{\prime \prime}$ 'W, J. Staniforth 00-069, 7 July 2000 (DAO).

The specimen cited above is an extension of the known distribution in the Territory (Cody 1996) of about 130 kilometers to the northeast of a site northeast of Mayo.

Draba porsildii G. A. Mulligan - YuKON: Pikatak Nunatak near Queen Mary Glacier, Kluane National Park, elevation over 8000 feet, $P$. Caswell PPC-2000$Y-345,13$ July 2000 (DAO) (determined by G. A. Mulligan).

This is a rare species in the Territory (Douglas et al. 1981). The specimen cited above from a site west of three previously known sites in the park represents the sixth location in the Territory (Cody 1996).

Draba scotteri G. A. Mulligan - YUKON: Rock Glacier, Kluane National Park, $60^{\circ} 25^{\prime} \mathrm{N} 137^{\circ} 05^{\prime} \mathrm{W}$, P. Caswell PPC-2000-Y-314, 13 Aug. 2000 (DAO); Alsek Trail, Kluane National Park, $60^{\circ} 45^{\prime} \mathrm{N} 137^{\circ} 46^{\prime} \mathrm{W}, P$. Caswell PPC-2000-Y-348, 8 June 2000 (DAO) (determined by G. A. Mulligan).

Douglas et al. (1981) considered this species rare in the Territory. The first specimen cited above extends the known range in the Territory about 50 kilometers southeast in the Park.

Erysimum cheiranthoides L., Wormseed Mustard YUKON: slumping eroding banks, cobbles and silty muck, Wind River, $65^{\circ} 47.45^{\prime} \mathrm{N} 135^{\circ} 13^{\prime} \mathrm{W}$, B. Bennett 00-122, 8 July 2000 (DAO); riverbar, Peel River Camp \#10, between Snake and Bonnet Plume rivers, $65^{\circ} 57$. $61^{\prime} N 134^{\circ} 25.68^{\prime} \mathrm{W}$, B. Bennett 00-704, 12 July 2000 (DAO) (determined by G. A. Mulligan).

The specimens cited above are an extension of the known range in the Territory (Cody 1996) of about 150 kilometers east of a site adjacent to the Dempster Hwy.

Lepidium sativum L., Garden Cress - YuKON: old experimental farm NW of Haines Junction, $60^{\circ} 46^{\prime} \mathrm{N}$ $137^{\circ} 35^{\prime}$ 'W, P. Caswell PPC-2000-Y-405, 2 July 2000 (DAO) (determined by G. A. Mulligan).

This introduced species was previously known in the Territory (Cody 1996) only from the vicinity of Dawson.

Lesquerella arctica (Wormsk. ex Hornem.) S. Watson ssp. arctica, Arctic Bladderpod - YUKON: undulating lower slope, Dryas outwash floodplain, Upper Bonnet Plume River Drainage Site \#110, J. Staniforth 00049, 6 July 2000 (DAO); open dolomite delta, Wind River, 6448.46'N 13441.34'W, B. Bennett 00-223, 3 July 2000 (B. Bennett Herbarium, photo DAO); calcareous scree, Wind River Camp \#2, 64⒌83'N $134^{\circ} 85^{\prime} \mathrm{W}$, B. Bennett 00-823, 4 July 2000 (DAO) (determined by G. A. Mulligan).

The specimens cited above are intermediate between sites adjacent to northern South Canol Road and a site just south of latitude $68^{\circ} \mathrm{N}$ (Cody 1996).

Lesquerella calderi Mulligan \& Porsild (L. arctica (Wormsk. ex Hornem.) S. Watson ssp. calderi (Mulligan \& Porsild) Hultén) - YUKON: vicinity of Snowdrift
Camp, Vuntut National Park, 68²1.4'N 139¹3.1'W, P. Caswell PPC-2000-Y-093, 19 June 2000 (DAO) (determined by G. A. Mulligan).

The specimen cited above is the northernmost yet found in the Territory (Cody 1996). It is from a site about 110 kilometers NNW of a site near the Mackenzie border just north of latitude $68^{\circ} \mathrm{N}$.

Subularia aquatica L. ssp. americana Mulligan \& Calder, Awlwort - YUKON: on sandy/gravelly shore of Davis Lake in valley of Eagle River, 66 $11.06^{\prime} \mathrm{N}$ $136^{\circ} 25.00^{\prime} \mathrm{W}$, R. Rosie 2138, 18 July 2000 (DAO) (determined by G. A. Mulligan).

The specimen cited above is an extension of the known range in the Territory (Cody 1996) of about 480 kilometers northwest from a site adjacent to the North Canol Road.

\section{SaXifragaceae}

Leptarrhena pyrolifolia (D. Don) Ser., Leather-leaved Saxifrage - YUKON: along alpine brook, Crescent Lake, 60¹1'00'N 131 ${ }^{\circ} 15^{\prime} 30^{\prime}$ 'W, R. Rosie 2127, 21 July 2000 (DAO).

The specimen cited above is the southernmost yet found in the Territory (Cody 1996). The nearest sites are near the northern South Canol Road about 175 kilometers to the northwest and in the vicinity of Frances Lake about 190 kilometers to the northeast. To the south it is frequent throughout much of British Columbia.

Parnassia fimbriata Koenig, Fringed Grass-of-Parnassus - YUKON: moist rivulet on east-facing mountain, Wind River Camp \#1, 6440.39'N 134³5. 96'W, B. Bennett 00-759, 2 July 2000 (B. Bennett Herbarium, photo DAO).

The specimen cited above is the northernmost yet found in the Territory (Cody 1996). The nearest known site is about 125 kilometers to the southwest in the vicinity of Mayo.

\section{ROSACEAE}

Dryas crenulata Juz. - YUKON: moist hummocky tundra, Upper Bonnet Plume River Drainage Site \#118, $64^{\circ} 24^{\prime} 12.6$ 'N $132^{\circ} 07^{\prime} 4^{\prime \prime} \mathrm{W}$, J. Staniforth 00-084, 7 July 2000 (DAO).

The specimen cited above is an extension of the known range in the Territory of about 100 kilometers to the southeast from a site adjacent to the Bonnet Plume River.

Dryas hookeriana Juz., Hooker's Mountain Avens YUKON: Richardson Mts., 6652'12'N 135'50'29'”W, G. Brunner 17A-00, 16 July 2000 (YUKH, photo DAO).

The specimen cited above is intermediate between a site west of the Wind River at latitude $65^{\circ} 16^{\prime} \mathrm{N}$ and a site near the Firth River at latitude $69^{\circ} 12^{\prime} \mathrm{N}$ (Cody et al. 2000).

Fragaria virginiana Duchesne ssp. glauca (S. Wats.) Staudt, Wild Strawberry - YUKON: riverbar, spreading in loose sand, Peel River Camp \#8, 65 $56.03^{\prime} \mathrm{N}$ 13456.03'W, B. Bennett 00-769, 9 July 2000 (DAO); loose sand near top of beach, Peel River, Taco Bar, $66^{\circ} 00.15^{\prime} \mathrm{N} 134^{\circ} 13^{\prime} \mathrm{W}$, B. Bennett 00-397, 13 July 2000 (DAO).

The specimens cited above are the northernmost yet found in the Territory and are north of a site adjacent to the northern Bonnet Plume River (Cody 1996; Cody et al. 2000). 
Potentilla nivea L., Snow Cinquefoil - YuKON: in dry Dryas/ lichen on mountain top, Richardson Mts., $66^{\circ}$ $51^{\prime} \mathrm{N} 135^{\circ} 51^{\prime} \mathrm{W}, \mathrm{R}$. Rosie 2156, 16 July 2000 (DAO).

The nearest site to the specimen cited above is about 100 kilometers from a site to the north and to the south about 300 kilometers to the southern Dempster Hwy.

Rosa woodsii Lindl., Western Rose - YUKON: dry steep slope below cliffs near coal mine shaft, Tantalus Butte, Carmacks, $67^{\circ} 07.23^{\prime} \mathrm{N} 136^{\circ} 15.23^{\prime} \mathrm{W}$, B. Bennett 001101, 30 May 2000 (B. Bennett Herbarium, photo DAO).

Douglas et al. (1981) considered this species rare in the Territory. The specimen cited above is an extension of the known range in the Territory (Cody 1996) of about 160 kilometers to the northwest from the vicinity of Whitehorse.

Rubus pedatus J. E. Sm., Creeping Raspberry - YUKON: along dirt road near Crescent Lake, 60¹1'41'N 13113'01'W, R. Rosie 2124, 21 July 2000 (DAO).

This rare species in the Territory was known to Douglas et al. (1981) and Cody (1996) from a single collection in the vicinity of Bennett Lake. The specimen cited above is an extension of the known range of about 200 kilometers to the east.

Rubus pubescens Raf., Dwarf Raspberry - YUKON: in meadow along brook draining warm spring, McPherson Lake, 61 ${ }^{\circ} 52^{\prime} 19^{\prime \prime} \mathrm{N} 129^{\circ} 36$ '34'W, R. Rosie 2095, 6 Sept. 2000 (DAO).

Cody et al. (1998) extended the known distribution in the Territory (Douglas et al. 1981) north to the vicinity of Frances Lake. The specimen cited above is a further extension of about 40 kilometers to the north.

Sanguisorba canadensis L. ssp. latifolia (Hook.) Calder \& Taylor, Canadian Burnet - YUKON: along gravelly/sandy beach near warm spring, McPherson Lake, 61 '52'19'”N 129³6'34'W, R. Rosie 2096, 6 Sept. 2000 (DAO).

The specimen cited above is an extension of the known range in the Territory (Cody 1996) of about 80 kilometers northwest of a site adjacent to the Nahanni Range Road.

Sibbaldia procumbens L., Sibbaldia - YUKON: strongly mounded-graminoid/moss/lichen pediment with frost boils, Upper Bonnet Plume River Drainage Site \#131, 64³1'19'N 132'51'39'W, J. Staniforth 00-090, 4-12 July 2000 (DAO).

The specimen cited above is an extension of the known range in the Territory (Cody 1996) of about 175 kilometers from a site adjacent to the North Canol Road and northeast of sites north of Mayo.

\section{FABACEAE (LEgUMinosae)}

Astragalus bodinii Sheldon, Bodin's Milk-vetch YUKON: huge riverbar system, Peel River Camp \#8, $65^{\circ} 56.3^{\prime} \mathrm{N} 134^{\circ} 58.84^{\prime} \mathrm{W}$, B. Bennett 00-768, 9 July 2000 (DAO).

The specimen cited above is the only specimen in the Territory (Cody 1996) from between latitudes $64^{\circ} \mathrm{N}$ and $67^{\circ} \mathrm{N}$ east of the Dempster Hwy.

Astragalus cicer L., Chick-pea Milk-vetch - YUKON: disturbed area near tailings dam, Sa Dena Hes Mine Site, $60^{\circ} 32.8^{\prime} \mathrm{N} 128^{\circ} 51.8^{\prime} \mathrm{W}, \mathrm{S}$. Withers SW00-179, 31 Aug. 2000 (DAO).
Cody et al. (1998) reported the first record of this introduced species in the La Biche area of the Territory and Cody et al. (2001) confirmed a large population along the Haines Road in the vicinity of Klukshu. The specimen cited above is an extension of the range about 280 kilometers to the west of the La Biche site.

Astragalus tenellus Pursh, Pulse Milk-vetch - YUKON: tussock tundra, Wind River, 644․63'N 134³8.3'W, B. Bennett 00-183, 3 July 2000 (B. Bennett Herbarium, photo DAO).

The specimen cited above is the northernmost yet found in the Territory (Cody 1996). It is an extension of the known range of about 115 kilometers to the northeast from a site south of latitude $64^{\circ} \mathrm{N}$.

Hedysarum boreale Nutt. ssp. mackenzii (Richards.) Welsh f. niveum (Boivin) Cody, Boreal Sweet-vetch - YuKON: vicinity of Snowdrift Camp, Vuntut National Park, 68²1.4'N 139¹3.1'W: P. Caswell PPC-2000Y-082, 22 June 2000 (DAO).

This white-flowered form was only known from two localities in the Territory at the time the flora (Cody 1996) was written (Pine Creek [67 $51^{\prime} \mathrm{N} 137^{\circ} 53^{\prime} \mathrm{W}$ type locality] and Richardson Mts., $\left.66^{\circ} 08^{\prime} \mathrm{N} 135^{\circ} 51^{\prime} \mathrm{W}\right)$.

Lotus corniculatus L., Birds-foot Trefoil - YUKON: disturbed area near tailings dam, Sa Dena Hes Mine Site, 60³2.8'N 128 51.8'W, S. Withers SW00-180, 31 Aug. 2000 (DAO).

This introduced species from Eurasia is new to the Flora of the Yukon Territory. It is found across Canada from Newfoundland to British Columbia. The genus Lotus can be separated from the genera Oxytropis and Astragalus as follows:

A. Flowers axillary, solitary or in small stalked heads or umbels; free portion of filaments (sometimes only every other one) dilated and usually broader than the anthers ....................

A. Flowers in spikes or racemes; none of the filaments dilated ........Astragalus and Oxytropis

Onobrychis viciifolia Scop., Sainfoin - YUKON: disturbed area near tailings dam, Sa Dena Hes Mine Site, $60^{\circ} 32.8^{\prime} \mathrm{N} 128^{\circ} 51.8^{\prime} \mathrm{W}$, S. Withers SW00-178, 31 Aug. 2000 (DAO).

This introduced species was known to Cody (1996) and Cody et al. (2002) only from the vicinity of Whitehorse. The specimen cited above is from a site about 350 kilometers to the east.

Oxytropis campestris (L.) DC. ssp. roaldii (Ostenf.) Cody - YuKON: shrubby riverbar, Wind River Outfitter's Camp, $64^{\circ} 34.43^{\prime}$ N $134^{\circ} 28.88^{\prime}$ 'W, B. Bennett 00233, 2 July 2000 (DAO).

The specimen cited above is an extension of the known range in the Territory (Cody 1996) of about 180 kilometers east of a site adjacent to the Dempster Hwy.

Oxytropis nigrescens (Pall.) Fisch. ssp. nigrescens, Blackish Locoweed - YUKON: alpine slope, Upper Bonnet Plume River Drainage Site \#100, 64²0'20'N $132^{\circ} 16$ '26”W, J. Staniforth 00-006, 5 July 2000 (DAO).

The specimen cited above is an extension of the known range in the Territory (Cody 1996) of about 80 kilometers east of a site adjacent to the upper Wind River. 
Trifolium pratense L., Red Clover - YUKON: dry roadside, Alaska Hwy. near Swift River, $60^{\circ} 00.3^{\prime} \mathrm{N} 131^{\circ}$ 06.0'W, S. Withers SW00-175, 30 Aug. 2000 (DAO).

The specimen cited above is an extension of known range of this introduced species in the Territory (Cody 1996) of about 125 kilometes east of the vicinity of Johnson's Crossing.

\section{ViOLACEAE}

Viola epipsila Ledeb. ssp. repens (Turcz.) Becker, Dwarf Marsh Violet - YUKON: in moist meadow in valley near Rudy Lakes, $60^{\circ} 13^{\prime} 00^{\prime \prime} \mathrm{N} 131^{\circ} 12^{\prime} 30^{\prime \prime} \mathrm{W}$, R. Rosie 2129, 23 July 2000 (DAO).

The specimen cited above is from a site intermediate between southern Canol Road and the vicinity of Watson Lake (Cody 1996).

Viola langsdorfii (Regel) Fisch., Alaska Violet YUKON: undulating lower slope, patches of shrubs amidst forb meadows, Upper Bonnet Plume River Drainage Site \#129, 64³1'26”N 132 49'52”'W, J. Staniforth 00-103, 8 July 2000 (DAO).

The specimen cited above is the northernmost yet found in the Territory (Cody 1996) about 230 kilometers northwest of a site just south of the north end of the Canol Road. It is a rare species in the Territory.

Viola nephrophylla Greene, Northern Bog Violet YUKON: in meadow along brook draining warm spring, McPherson Lake, 61 ${ }^{\circ} 52^{\prime} 19^{\prime \prime} \mathrm{N} 129^{\circ} 36^{\prime} 34^{\prime \prime} \mathrm{W}$, R. Rosie 2100, 6 Sept. 2000 (DAO).

This is a rare species in the Territory that Douglas et al. (1981) knew only from the vicinity of Watson Lake. Cody et al. $(1998,2000)$ reported new sites from the Beaver River and Mount Billings. The specimen cited above is an extension of the known range about 100 kilometers northwest of Mount Billings.

\section{Onagraceae}

Circaea alpina L. ssp. alpina, Enchanter's Nightshade - YUKON: in meadow along brook draining warm spring, McPherson Lake, 61 ${ }^{\circ} 52^{\prime} 19^{\prime \prime} \mathrm{N} 129^{\circ} 36^{\prime} 34^{\prime \prime} \mathrm{W}$, R. Rosie 2094, 6 Sept. 2000 (DAO).

Douglas et al. (1981) knew this rare species in the Territory from a single collection from the Beaver River. Cody et al. (1998) reported new sites from the La Biche River and Frances Lake. The specimen cited above is an extension of about 60 kilometers northwest of Frances Lake.

Epilobium hornemannii Rchb., Hornemann's Willowherb - YUKON: strongly mounded undulating alpine valley lower slope, Upper Bonnet Plume River Drainage Site \#154, 64²8'19”N 132¹9'21'W, J. Staniforth 00-152, 12 July 2000 (DAO).

The specimen cited above is an extension of the known range in the Territory of about 130 kilometers east of a site between latitudes $64^{\circ} \mathrm{N}$ and $66^{\circ} \mathrm{N}$ west of longitude $135^{\circ} \mathrm{W}$.

Epilobium palustre L., Swamp Willowherb - YUKON: Larix laricina/Picea mariana/Carex media/Eriophorum marsh, Peel River Camp \#10 between Snake and Bonnet Plume rivers, $65^{\circ} 57.61^{\prime} \mathrm{N} 134^{\circ} 25.68^{\prime} \mathrm{W}$, B. Bennett 00-707, 12 July 2000 (DAO).

The specimen cited above is an extension of the known range in the Territory (Cody 1996) of about 75 kilometers east of the only known site between latitudes $64^{\circ} \mathrm{N}$ and $67^{\circ} \mathrm{N}$.

\section{Apiaceae (Umbelliferae)}

Cicuta maculata L. var. angustifolia Hook., Spotted Water-hemlock - YUKON: in meadow along brook draining warm spring, McPherson Lake, 61 ${ }^{\circ} 52^{\prime} 19^{\prime \prime} \mathrm{N}$ 129³6’34”'W, R. Rosie 2083, 6 Sept. 2000 (DAO).

This is a rare species in the Yukon Territory (Douglas et al. 1981). The specimen cited above is an extension of the known range in the Territory (Cody 1996; Cody et al. 2000) of about 230 kilometers northwest of a site west of longitude $127^{\circ} \mathrm{W}$.

Osmorhiza depauperata Phil., Blunt-fruited Sweetcicely - YUKON: Rock Glacier, Kluane National Park, $60^{\circ} 25^{\prime} \mathrm{N} 137^{\circ} 05^{\prime} \mathrm{W}, P$. Caswell PPC-2000-Y-428, 13 Aug. 2000 (Kluane National Park, photo DAO); same lcoality P. Caswell 437 (ALA, photo DAO); in Salix barclayi stand on outwash fan, ca. $3 \mathrm{mi}$. SW of Onion Lake, $60^{\circ} 6^{\prime} \mathrm{N} 137^{\circ} 30^{\prime} \mathrm{W}$, H.L. \& I.J. Weaver 235,18 July 1975 (photo DAO).

Cody (1996) knew this species only in the southeast of the Territory. The specimens cited above are an extension of the known range of about 375 kilometers to the west. It is however known in northwestern British Columbia and adjacent Alaska.

\section{Pyrolaceae}

Pyrola minor L., Lesser Wintergreen - YUKON: on small plateau above lake, S side of Trout Lake, $68^{\circ}$ 49'27'N 138 45' '”'W, J. M. Line 2000-26, 25 July 2000 (DAO).

Cody (1996) knew this species in the Territory only as far north as about $64^{\circ} 30^{\prime} \mathrm{N}$. Cody et al. (2001) extended the range northward to $66^{\circ} 49^{\prime} \mathrm{N}$. The specimen cited above is a further northward extension of about 280 kilometers northwest of the Vittrewka Lake site.

\section{Ericaceae}

Andromeda polifolia L., Bog Rosemary - YUKON: undulating lower slope, spruce/shrub/lowshrub/forb/ moss, Upper Bonnet Plume River Drainage Site \#105, $64^{\circ} 26^{\prime} 6^{\prime}$ 'N $132^{\circ} 15^{\prime} 28^{\prime \prime}$ 'W, J. Staniforth 00-001, 5 July 2000 (DAO).

The specimen cited above is an extension of the known range in the Territory (Cody 1996) of about 100 kilometers southeast of a site adjacent to the Bonnet Plume River.

Kalmia polifolia Wang., Bog-laurel - YUKON: undulating upper slope, small sedge meadow alongside seepage stream, Upper Bonnet Plume River Drainage near

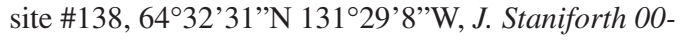
115, 9 July 2000 (DAO).

The specimen cited above is extension of the known range in the Territory (Cody 1996) of about 130 kilometers east of a site west of longitude $135^{\circ} \mathrm{W}$.

\section{Primulaceae}

Primula egaliksensis Wormsk., Greenland Primrose - YUKON: riverbar, Wind River Camp \#1, 64²0.39’ N $134^{\circ} 35.96^{\prime} \mathrm{W}$, B. Bennett 00-750, 2 July 2000 (DAO).

The specimen cited above is the northernmost yet found in the Territory (Cody 1996). The nearest site is adjacent to the northern part of the South Canol Road about 350 kilometers to the south. 


\begin{abstract}
Menyanthaceae
Menyanthes trifoliata L., Buckbean - YUKON: in basin bog in old oxbow on Eagle River, Eagle Plains, $66^{\circ}$ $16^{\prime} \mathrm{N} 136^{\circ} 31$ 'W, R. Rosie 2154, 18 July 2000 (DAO).

The specimen cited above is from a site intermediate between a site adjacent to the Porcupine River about 150 kilometers to the northwest and about 200 kilometers to the southwest adjacent to the Dempster Hwy. (Cody 1996).
\end{abstract}

\section{Polemoniaceae}

Phlox hoodii Richards., Moss Phlox - Yukon: hummock tussock tundra, Wind River, $64^{\circ} 54^{\prime} 2^{\prime \prime} \mathrm{N}$ $134^{\circ} 41^{\prime} 25^{\prime \prime} \mathrm{W}$, B. Bennett 00-164, 4 July 2000 (DAO); vicinity of Snowdrift Camp, $68^{\circ} 21.4^{\prime} \mathrm{N} 139^{\circ} 13.1^{\prime} \mathrm{W}$, P. Caswell PPC-2000-Y-121, 22 June 2000 (DAO).

The specimens cited above are the northernmost yet found in the Territory (Cody 1996). The first specimen is an extension of about 225 kilometers to the northeast from a site adjacent the southern Dempster Hwy. and the second specimen is a further extension of about 450 kilometers to the north.

Polemonium acutiflorum Willd., Tall Jacob's-ladder YUKON: strongly mounded undulating alpine valley

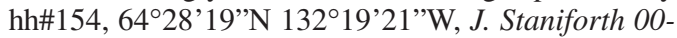
151, 12 July 2000 (DAO); undulating upper slope, moist hummocky tundra, Upper Bonnet Plume River

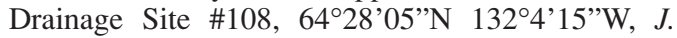
Staniforth 00-034, 5 July 2000 (DAO).

The specimens cited above are an extension of the known range in the Territory (Cody 1996) of about 140 kilometers northeast of a site just west of longitude $135^{\circ} \mathrm{W}$.

\section{BoraginaCEAE}

Eritrichium splendens Kearney, Showy Alpine Forgetme-not - YUKON: in steep loose talus, east bank confluence of Royal Creek, Wind River Camp \#3, 65 06.83 'N $134^{\circ} 47.12^{\prime} \mathrm{W}$, B. Bennett 00-220, 4 July 2000 (DAO).

The specimen cited above is an extension of the known range in the Territory (Cody 1996) of about 150 kilometers east of a site adjacent to the Dempster Hwy.

Lappula occidentalis (Wats.) Greene, Western Stickseed - YUKON: common along disturbed roadsides, Dempster Hwy., $65^{\circ} 09.19^{\prime}$ N $138^{\circ} 21.4^{\prime}$ 'W, B. Bennett 00-074, 10 June 2000 (DAO).

The specimen cited above is an extension of the known range in the Territory of about 140 kilometers north of sites in the vicinity of Dawson City.

\section{VERBENACEAE}

Verbena hastata L., Blue Vervain (Figure 4) - YUKON: roadside established and spreading, highway adjacent to former Experimental Farm, Haines Junction, $61^{\circ}$ 46’30'N 137 33'W, P. Caswell s.n., 13 Aug. 2000 (B. Bennett Herbarium, photo DAO).

The family Verbenaceae is new to the Territory (Cody 1996). It resembles the mint family in having an ovary that ripens into 2-4 seed-like nutlets. It can be separated from the family Lamiaceae (Labiatae) as follows:

A. Anthers 4, in pairs; ovary not deeply

4-lobed; stems round .............. Verbenaceae

A. Anthers $2-4$, rarely 3 , ovary deeply

4-lobed; stems often square ............Lamiaceae

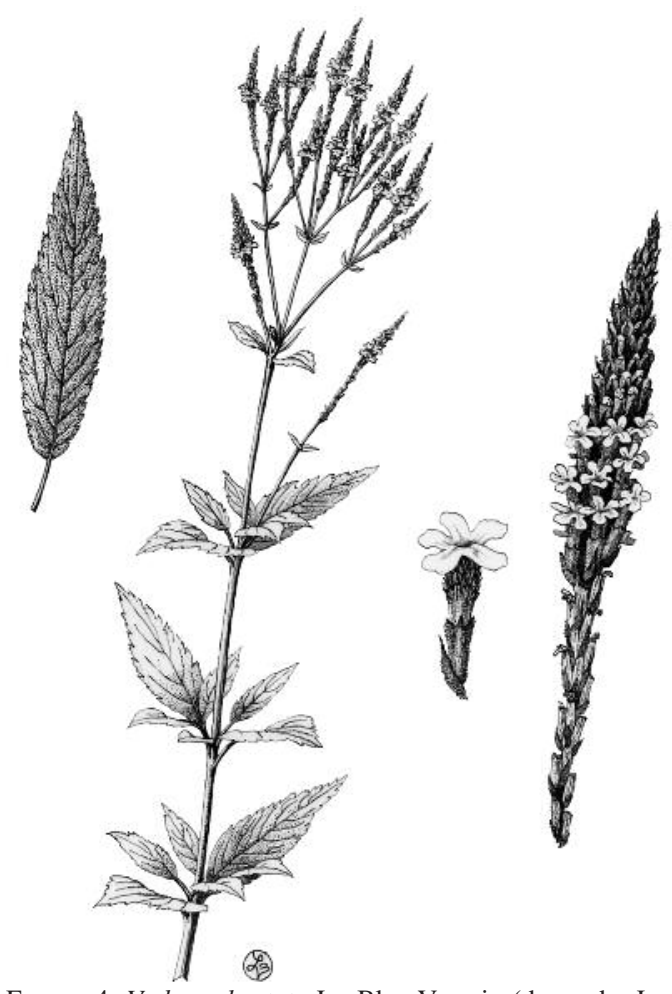

FIgURE 4. Verbena hastata L., Blue Vervain (drawn by Lee Mennell).

Verbena hastata is an erect perennial; stems to $1 \mathrm{~m}$ or more, branched above, pubescent; leaves lanceolate or lance-oblong to narrowly ovate, to $18 \mathrm{~cm}$ long, acuminate, coarsely incisedserrate, scrabrous-pubescent; spikes strict, pencil-like, usually numerous in a panicle, compact, with mostly imbricated fruiting calyxes, bracts lance-subulate, mostly shorter than the pubescent calyx (2.5-3 mm long); calyx with finally incurving subulate-tipped lobes; corolla-limb violet-blue, 3-4.5 mm broad; nutlets $2 \mathrm{~mm}$ long, nearly smooth or faintly striate. Nova Scotia to southern British Columbia, south to Florida, Texas and California.

\section{LAMiACEAE (LABIATAE)}

Prunella vulgaris L. ssp. lanceolata (Bart.) Hultén, Heal-all (Figure 5) - YUKON: along gravelly/sandy beach near warm spring/McPherson Lake, 61 ${ }^{\circ} 52^{\prime} 19^{\prime} \mathrm{N}$ 129³6’34”W, R. Rosie 2093, 6 Sept. 2000 (DAO).

Prunella vulgaris ssp. lanceolata is the North American component of a circumpolar species which is new to the flora of the Yukon Territory (Cody 1996). The genus Prunella can be separated from Galeopsis and Stachys as follows:

A. Calyx deeply bilabiate, ten-nerved,

reticulate-veiny, closed in fruit, the upper

lip flat and 3-toothed ................Prunella

A. Calyx not strongly bilabiate, open in fruit,

the lobes or teeth sub-equal ....Galeopsis and Stachys

Prunella vulgaris ssp. lanceolata has a stem ascending or erect from a short rhizome; leaves lanceolate to oblong, gradually narrowed or cuneate at base, shallowly dentate; bracts 


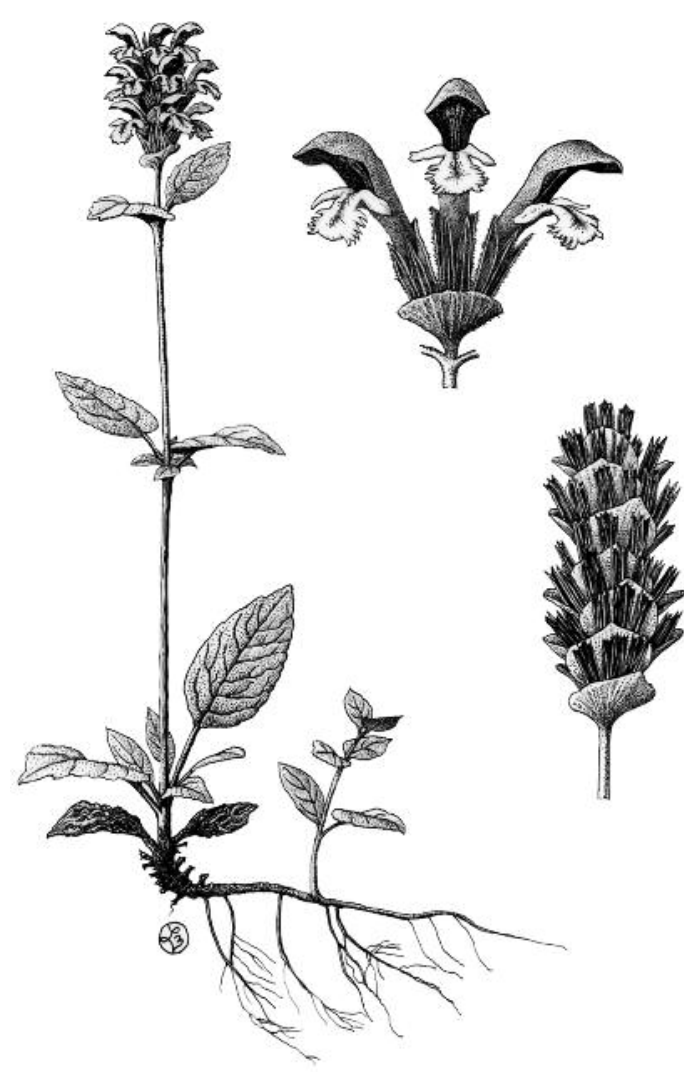

FIGURE 5. Prunella vulgaris L. ssp. lanceolata (Bart.) Hultén, Heal-all (drawn by Lee Mennell).

ciliate; moist open woods, fields and roadsides; Newfoundland to British Columbia and Alaska and south to Florida, Texas and California.

\section{SCROPHUlariaceae}

Castilleja pallida (L.) Spreng. var. caudata (Pennell) Boivin, C. caudata (Pennell) Rebr., Port Clarence Paintbrush - YUKON: moist pockets in talus, Kotaneelee Range, $60^{\circ} 14.31^{\prime} \mathrm{N} 124^{\circ} 07.19^{\prime} \mathrm{W}$, B. Bennett $98-567$, 19 June 1998 (B. Bennett Herbarium, photo DAO) (determined by M. Egger).

The specimen cited above is an extension of the known range in the Territory (Cody 1996) of about 550 kilometers east of a site in the vicinity of Carcross.

Linaria vulgaris Miller, Butter-and-eggs, Yellow-toadflax - YUKON: Haines Junction, $60^{\circ} 44^{\prime} \mathrm{N} 137^{\circ} 31^{\prime} \mathrm{W}$, L. Freese PPC-2000-4-408, 20 July 2000 (DAO).

The specimen cited above of this introduced species is from only the fourth known locality in the Territory (Cody 1996).

Mimulus guttatus DC., Yellow Monkeyflower YUKON: in meadow along brook draining warm spring, McPherson Lake, 61'52'19'” 12936'34'W, R. Rosie 2098, 6 Sept. 2000 (DAO).

This species was considered rare in the Territory by Douglas et al. (1981). The specimen cited above is from the northernmost site yet found in the Territory (Cody 1996; Cody et al. 1998), about 40 kilometers north of a site in the vicinity of Frances Lake.

Pedicularis lanata Cham. \& Schlecht., Woolly Lousewort - YUKON: severely mounded lower slope tussock tundra, Upper Bonnet Plume River Drainage Site \#140, 64¹9'23'N 131 '35'19'W, J. Staniforth 00-118, 14 July 2000 (DAO); undulating upper slope, moist hummocky tundra, Upper Bonnet Plume River Drainage

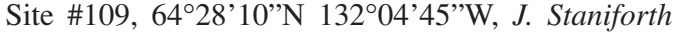
00-005, 00-009, 5 July 2000 (DAO).

The specimens cited above are the easternmost yet found between latitudes $64^{\circ} \mathrm{N}$ and $66^{\circ} \mathrm{N}$. They are about 140 kilometers southeast of a site about the middle of the Bonnet Plume River drainage.

\section{OROBANCHACEAE}

Orobanche fasciculata (Cham. \& Schleht.) Fedtsch, Ground-cone - YUKON: breakwater of Slim's River Causeway, $60^{\circ} 59.5^{\prime} \mathrm{N} 138^{\circ} 29^{\prime} \mathrm{W}$, P. Caswell PPC2000-Y-427 (Kluane National Park Herbarium, photo DAO).

This species was considered rare in the Territory by Douglas et al. (1981). The specimen cited above is an extension of the known distribution in the Territory (Cody 1996) of about 190 kilometers west of the vicinity of Whitehorse.

\section{LENTIBULARIACEAE}

Utricularia minor, Lesser Bladderwort - YUKON: in small stagnant slough in the middle of Eriophorum tussock tundra habitat between Trout Lake and the Babbage River, $68^{\circ} 49^{\prime} \mathrm{N} 138^{\circ} 45^{\prime} \mathrm{W}, J$. M. Line 200012, 28 July 2000 (DAO).

Cody (1996) knew this rare species in the Territory only as far north as about latitude $64^{\circ} 30^{\prime} \mathrm{N}$ adjacent to the Dempster Hwy. The specimen cited above is an extension of the known distribution of about 475 kilometers to the north.

\section{Plantaginaceae}

Plantago major L., Common Plantain - YUKON: parking lot, Auriol Trail, Kluane National park, $60^{\circ} 42^{\prime} \mathrm{N}$ $137^{\circ} 27^{\prime} \mathrm{W}$, P. Caswell PPC-2000-4-440, 4 July 2000 (DAO).

The specimen cited above is an extension of the known range in the Territory (Cody 1996) of about 115 kilometers west of the vicinity of Whitehorse.

\section{RUbiaceae}

Galium trifidum L., Small Bedstraw - YukON: in basin bog in old oxbow on Eagle River, 66 $16^{\circ} \mathrm{N} 136^{\circ} 31^{\prime} \mathrm{W}$, R. Rosie 2157, 18 July 2000 (DAO).

The specimen cited above is intermediate between a site adjacent to the Dempster Hwy. about 160 kilometers to the southwest and a site adjacent to the Bell River about 140 kilometers to the north (Cody 1996).

\section{AdoxaceaE}

Adoxa moschatellina L., Moschatel - YukON: alder/

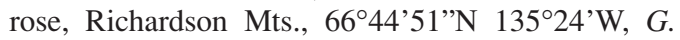
Brunner 24B-00, 17 July 2000, (YUKH, photo DAO).

Cody knew this species in the Territory (1996) as far north as the southern Dempster Hwy. and then disjunct to the Porcupine River near the Alaska border. The specimen cited above 
is an extension of the known range about 260 kilometers northeast of the Dempster sites and 240 kilometers southeast of the Porcupine River site.

\section{Asteraceae (Compositae)}

Antennaria rosea Greene ssp. confinis (Greene) Bayer - YUKON: in open meadow under Salix near outfitter cabin, McClusky Lake, Wind River, 64³4.19’ N $134^{\circ} 25.77^{\prime} \mathrm{W}$, B. Bennett 00-343, 2 July 2000 (DAO).

The specimen cited above is an extension of the known range in the Territory (Cody 1996) of about 125 kilometers northeast of a site in the vicinity of Mayo.

Arnica angustifolia Vahl ssp. attenuata (Greene) Douglas \& Ruyle-Douglas, Alpine Arnica - YUKON: undulating lower slope, open spruce/lichen/grass/forb, Upper Bonnet Plume River Drainage Site \#147, $64^{\circ} 22^{\prime} 38^{\prime}$ 'N $132^{\circ} 47^{\prime} \mathrm{W}, \mathrm{J}$. Staniforth 00-141, 10 July 2000 (DAO).

The specimen cited above is an extension of the known range in the Territory (Cody 1996) of about 130 kilometers northeast of a site northeast of Mayo.

Arnica chamissonis Less. ssp. chamissonis, Meadow Arnica - YUKON: roadside in open white spruce forest near Canyon Lake, $61^{\circ} 09^{\prime} \mathrm{N} 136^{\circ} 58.2^{\prime} \mathrm{W}$, S. Withers SW00-156, 6 Aug. 2000 (DAO); in meadow along brook draining warm spring, McPherson Lake, $61^{\circ}$ 52'19'” 129'36'34'W, R. Rosie 2086, 6 Sept. 2000 (DAO).

The specimens cited above are northern extensions of the range of this rare subspecies in the Territory (Cody 1996; Cody et al. 2000). The first specimen is an extension of about 60 kilometers northeast from the vicinity of Haines Junction and the second specimen is an extension of about 40 kilometers northwest from the vicinity of Frances Lake.

Arnica griscomii Fern. ssp. frigida (C. A. Mey. ex Iljin) S. J. Wolf, Snow Leopardbane - YUKON: undulating upper slope, steep alpine ridge, rock, rubble, bare soil and sparse vegetation, Upper Bonnet Plume River Drainage Site \#125, 64³2'45'N 132 50'48'W, J. Staniforth 00-101, 8 July 2000 (DAO).

The specimen cited above is an extension of the known range in the Territory (Cody 1996) of about 100 kilometers east of a site just west of the Wind River.

Artemisia dracunculus L., Tarragon - YuKON: damp open meadow with dwarf birch, Meadow near Atthilu Lake, 61⒕2'N 136 55.9'W, S. Withers SW00-148, 5 Aug. 2000 (DAO); near Aishihik Lake at south end of lake, $61^{\circ} 25^{\prime} \mathrm{N} 137^{\circ} 15^{\prime} \mathrm{W}$, G. Brunner 496-01, 12 Aug. 2001 (DAO); very common in an area covering about 100 square meters on both sides of the road, Giltana Slough, Aishihik Valley, 6114'04'N 136 57'22'W, B. Bennett 01-064, 11 Aug. 2001 (DAO).

This species which is restricted to southwestern Yukon (Cody 1996) was considered rare in the Territory by Douglas et al. (1981). The specimens cited above are an extension of the known range of about 60 kilometers northeast of the vicinity of Haines Junction.

Aster modestus Lindl. in DC., Western Bog Aster YUKON: in meadow along brook draining warm spring,
McPherson Lake, 61 52'19'N 129'36'34'W, R. Rosie 2087, 6 Sept. 2000 (DAO).

This species was considered rare in the Territory by Douglas et al. (1981). The specimen cited above is an extension of the known range in the Territory (Cody 1996) of about 230 kilometers northwest of a site east of Watson Lake.

Bidens cernua L., Nodding Beggarticks - YUKON: Horseshoe Slough Habitat Protection Area near Mayo, 6326'N 13506'W, D. Mossop 16, July 2000 (DAO).

Douglas et al. (1981) considered this species which was known only from a single site in the extreme southeast adjacent to the Beaver River as rare in the Territory. The specimen cited above is an extension of the known range of about 700 kilometers to the northwest.

Chrysanthemum integrifolium Richards., Entire-leaved Daisey - YUKON: undulating lower slope, shrub thicket with pockets of lichen, Upper Bonnet Plume River Drainage Site \#111, 64²2'10'”N 132¹9'49'”W, J. Staniforth 00-051, 6 July 2000 (DAO).

The specimen cited above is an extension of the known range in the Territory (Cody 1996) of about 180 kilometers southeast of a site between the Wind and Bonnet Plume rivers.

Hieracium albiflorum Hook., White Hawkweed (Figure 6) - YUKON: along dirt mining exploration road on mountain slope, Crescent Lake, 60 $10^{\prime} 03^{\prime \prime} \mathrm{N} 131^{\circ} 06^{\prime}$ 55'W, R. Rosie 2106, 24 July 2000 (DAO).

Cody (1996) suggested that this species should be looked for in southwestern Yukon. It has now been found and should be added to the list of rare species (Douglas et al. 1981).

Matricaria perforata Mérat., Scentless Mayweed YUKON: disturbed area near tailings dam, Sa Dena Hes Mine Site, $60^{\circ} 32.8^{\prime} \mathrm{N} 125^{\circ} 51.8^{\prime} \mathrm{W}, S$. Withers SW00-177, 31 Aug. 2000 (DAO); open roadside, Faro Mine Road, $62^{\circ} 21.6^{\prime} \mathrm{N} 133^{\circ} 25^{\prime} \mathrm{W}, \mathrm{S}$. Withers SWOO250, 5 Sept. 2000 (DAO); disturbed area by road, Caribou Lake Road, 60³1.1'N 134¹9.5'W, S. Withers SW00-164, 7 Aug. 2000 (DAO).

Cody (1996) knew this introduced species from only the vicinities of Frances Lake and Ross River. Cody et al. $(2000,2002)$ added additional sites to Nisutlin Delta and by the Top of the World Hwy. It is now becoming more widespread in disturbed areas.

Senecio indecorus Greene, Rayless Mountain Butterweed - YUKON: gravelly riverbar, Wind River Camp \#6, 6540.46’N $135^{\circ} 11.76^{\prime} \mathrm{W}$, B. Bennett 00-849, 7 July 2000 (DAO).

The specimen cited above is the northernmost yet found in the Territory (Cody 1996). It is an extension of about 250 kilometers north of sites in the vicinity of Stewart Crossing.

Senecio sheldonensis A.E. Porsild, Mount Sheldon Ragweed - YUKON: convex mid slope, Upper Bonnet Plume River Drainage Site \#128, 64³2'37'N 13250'26"W, J. Staniforth 00-095, 8 July 2000 (DAO).

The specimen cited above is from a location about 60 kilometers southeast of the northernmost site mapped by Cody (1996) adjacent to the Bonnet Plume River. 
Senecio streptanthifolius Greene, Rocky Mountain Groundsel - YUKON: steep active solifluxion slope across river from camp, Wind River Camp \#1, $64^{\circ} 40.39^{\prime} \mathrm{N} 134^{\circ} 35.96^{\prime} \mathrm{W}$, B. Bennett 00-173, 3 July 2000 (DAO); riverbar, Wind River Camp \#6, 65 40. $46^{\prime} \mathrm{N} 135^{\circ} 11.76^{\prime} \mathrm{W}$, B. Bennett 00-857, 7 July 2000 (DAO).

The specimens cited above are the northernmost yet found in the Territory (Cody 1996), about 200 kilometers north of a site northeast of Mayo.

Senecio tundricola Tolm., Tundra Ragwort - YUKON: convex lower slope, open willow/lichen/moss, Upper Bonnet Plume River Drainage near Site \#137, 64³1' 57'N 131'32'42”'W, J. Staniforth 00-116, 9 July 2000 (DAO).

The specimen cited above is the easternmost yet found in the Territory. It is from a site about 240 kilometers east of a site just east of the Hart River.

Senecio vulgaris L., Common Groundsel - YUKON: flower bed at Kluane Park Inn, Haines Junction, $60^{\circ} 44^{\prime} \mathrm{N} 137^{\circ} 31^{\prime} \mathrm{W}$, P. Caswell PPC-2000-Y-471, 14 Aug. 2000 (DAO).

This weed of cultivated ground was previously known from Dawson (Cody 1996) and Whitehorse (Cody et al. 2000).

Solidago canadensis L. var. salebrosa (Piper) Jones, Canada Goldenrod - Yukon: Slims West Trail, Kluane National Park, $61^{\circ} 00.5^{\prime} \mathrm{N} 138^{\circ} 29^{\prime} \mathrm{W}, P$. Caswell PPC-2000-Y-475, 22 July 2000 (DAO); dry roadside, Alaska Hwy. west of Yukon River, 60 $35.6^{\prime} \mathrm{N} 134^{\circ}$ 46.8'W, S. Withers SW00-165, 7 Aug. 2000 (DAO).

The specimens cited above are the first known from the southwest part of the Territory.

Solidago multiradiata Ait., Northern Goldenrod YUKON: valley floor, moist shrub/graminoid/moss, Upper Bonnet Plume River Drainage Site \#114, $64^{\circ} 24^{\prime} 51^{\prime \prime} \mathrm{N} 132^{\circ} 23^{\prime} \mathrm{W}$, J. Staniforth 00-067, 6 July 2000 (DAO).

The specimen cited above is an extension of the known range in the Territory (Cody 1996) of about 115 kilometers southeast of a site adjacent to the Bonnet Plume River.

Sonchus asper (L.) Hill, Spiny Sow-thistle - YUKON: flower bed at Kluane Park Inn, Haines Junction, $60^{\circ} 44^{\prime} \mathrm{N} 137^{\circ} 31^{\prime} \mathrm{W}$, P. Caswell PPC-2000-Y-479, 13 Aug. 2000 (DAO).

The only site known to Cody (1996) of this introduced weedy species was in the vicinity of Dawson.

Taraxacum lyratum (Ledeb.) DC. - YUKON: convex lower slope, open willow/lichen/moss, Upper Bonnet Plume River Drainage near Site \#137, 64³1'57'N $131^{\circ} 32^{\prime} 42^{\prime \prime} W$, J. Staniforth 00-117, 9 July 2000 (DAO).

The specimen cited above is an extension of the known range in the Territory of about 190 kilometers east of a site just north of latitude $64^{\circ} \mathrm{N}$.

\section{Acknowledgments}

We thank Gerald A. Mulligan for the identification of Brassicaceae (Cruciferae) specimens; George Argus

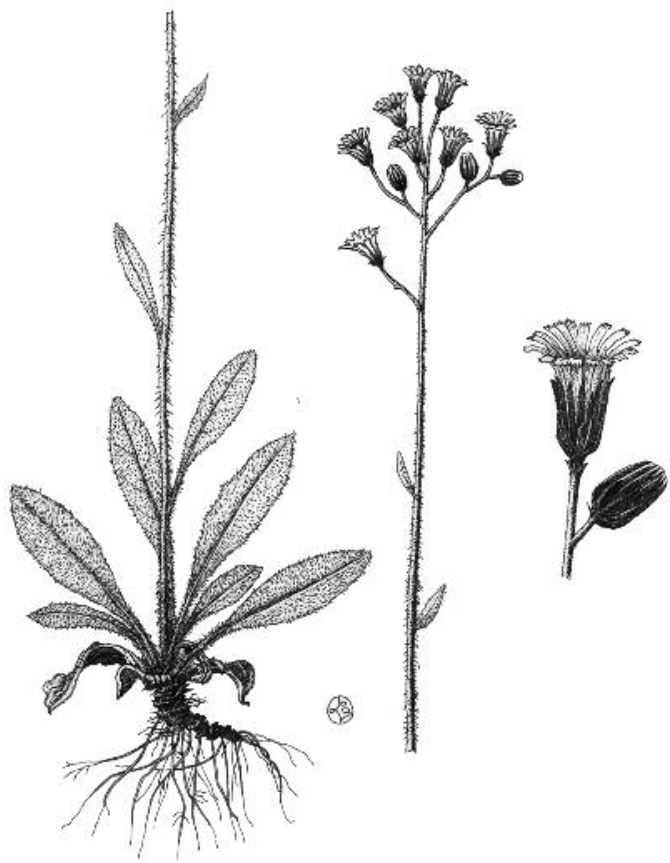

FIGURE 6. Hieracium albiflorum Hook., White Hawkweed (drawn by Lee Mennell).

for the identification of Salix specimens; Stephen J. Darbyshire for the identification of $\times$ Elyhordeum macounii, Elymus elongatus ssp. ponticus, Elymus junceus and Elymus trachycaulus ssp. novae-angliae; Laurie Consaul for the identification of Puccinellia distans; Phil Caswell, Jennifer Line, Rhonda Rosie and Stu Withers for their constributions of specimens, many representing very substantial range extensions; Lee Mennell for his excellent drawings; Margaret Cody for assisting the senior author with collections in the summer of 2001 in southern Yukon; Paul Catling for reviewing an earlier version of this manuscript, and especially Leslie Durocher for the many hours inputting this information on her computer.

\section{Literature Cited}

Cody, W. J. 1996. Flora of the Yukon Territory. National Research Council (NRC) Press, Ottawa, Ontario, Canada. 643 pages.

Cody, W. J., C. E. Kennedy, and B. Bennett. 1998. New Records of Vascular Plants in the Yukon Territory. Canadian Field-Naturalist 112: 289-328.

Cody, W. J., C. E. Kennedy, and B. Bennett. 2000. New Records of Vascular Plants in the Yukon Territory II. Canadian Field-Naturalist 114: 417-443.

Cody, W. J., C. E. Kennedy, and B. Bennett. 2001. New Records of Vascular Plants in the Yukon Territory III. Canadian Field-Naturalist 115: 301-322.

Cody, W. J., C. E. Kennedy, B. Bennett, and V. Loewen. 2002. New records of Vascular Plants in the Yukon Territory IV. Canadian Field-Naturalist 116: 446-474. 
Douglas, G. W., G. W. Argus, H. L. Dickson, and D. F. Brunton. 1981. The Rare Vascular Plants of the Yukon. Syllogeus 28: 1-96.

Douglas, G. W., G. B. Straley, D. Meidinger, and J. Pojar. 1998. Illustrated Flora of British Columbia, Volume 1 Gymnosperms and Dicotoledons (Aceraceae through Asteraceae). British Columbia Ministry of Environment, Lands and Parks and Ministry of Forests. 436 pages.

Douglas, G. W., G. B. Straley, D. Meidinger, and J. Pojar. 1998. Illustrated Flora of British Columbia, Volume 2 Dicotyledons (Balsaminaceae through Cuscutaceae). British Columbia Ministry of Environment, Lands and Parks and Ministry of Forests. 401 pages.

Douglas, G. W., D. Meidinger, and J. Pojar. 1999. Illustrated Flora of British Columbia, Volume 3 Dicotyledons (Diapensiaceae through Onograceae). British Columbia Ministry of Environment, Lands and Parks and Ministry of Forests. 423 pages.

Douglas, G. W., D. Meidinger, and J. Pojar. 1999. Illustrated Flora of British Columbia, Volume 4 Dicotyledons (Orobanchaceae through Rubiaceae). British Columbia Ministry of Environment, Lands and Parks and Ministry of Forests. 427 pages.
Douglas, G. W., D. Meidinger, and J. Pojar. 2000. Illustrated Flora of British Columbia, Volume 5 Dicotyledons (Salicaceae through Zygophyllaceae) and Pteridophytes. British Columbia Ministry of Environment, Lands and Parks and Ministry of Forests. 361 pages.

Douglas, G. W., D. Meidinger, and J. Pojar. 2001. Illustrated Flora of British Columbia, Volume 6, Monocotyledons (Acoraceae through Najadaceae). British Columbia Ministry of Environment, Lands and Parks Ministry of Forests. 361 pages.

Douglas, G. W., D. Meidinger, and J. Pojar. 2001. Illustrated Flora of British Columbia, Volume 7, Monocotyledons (Orchidaceae through Zosteraceae). British Columbia Ministry of Environment, Lands and Parks Ministry of Forests. 379 pages.

La Frankie, Jr., J. V. 1986. Morphology and Taxonomy of the New World species of Maianthemum (Liliaceae). Journal of the Arnold Arboretum 67(4): 371-439.

Porsild, A. E. 1951. Botany of Southeastern Yukon adjacent to the Canol Road. National Museum Bulletin Number 121. 400 pages.

Received 9 October 2002

Accepted 10 October 2003 